\title{
A Dialogical Approach to Readiness for Change towards Sustainability in Higher Education Institutions: The Case of the SDGs Seminars at the Universidad Politécnica de Madrid
}

\author{
Irene Ezquerra-Lázaro ${ }^{1, * \mathbb{D}}$, Asunción Gómez-Pérez ${ }^{2}$, Carlos Mataix ${ }^{1,3}$, Miguel Soberón ${ }^{1}$ (D), \\ Jaime Moreno-Serna ${ }^{1}(\mathbb{D})$ and Teresa Sánchez-Chaparro ${ }^{1,3} \mathbb{D}$ \\ 1 Centro de Innovación en Tecnología para el Desarrollo Humano, \\ Universidad Politécnica de Madrid (itdUPM), 28040 Madrid, Spain; carlos.mataix@upm.es (C.M.); \\ miguel.soberon@upm.es (M.S.); jaime.moreno@upm.es (J.M.-S.); teresa.sanchez@upm.es (T.S.-C.) \\ 2 Department of Artificial Intelligence, Escuela Técnica Superior de Ingenieros Informáticos, \\ Universidad Politécnica de Madrid, Boadilla del Monte, 28660 Madrid, Spain; \\ asunciondemaria.gomez@upm.es \\ 3 Department of Organizational Engineering, Business Administration and Statistics, \\ Escuela Técnica Superior de Ingenieros Industriales, Universidad Politécnica de Madrid, \\ 28006 Madrid, Spain \\ * Correspondence: irene.ezquerra@upm.es; Tel.: +34-648-05-27-03
}

Citation: Ezquerra-Lázaro, I.;

Gómez-Pérez, A.; Mataix, C.;

Soberón, M.; Moreno-Serna, J.; Sánchez-Chaparro, T. A Dialogical Approach to Readiness for Change towards Sustainability in Higher

Education Institutions: The Case of the SDGs Seminars at the Universidad Politécnica de Madrid. Sustainability 2021, 13, 9168. https:// doi.org/10.3390/su13169168

Academic Editor:

Carla Maria Marques Curado

Received: 30 July 2021

Accepted: 12 August 2021

Published: 16 August 2021

Publisher's Note: MDPI stays neutral with regard to jurisdictional claims in published maps and institutional affiliations.

Copyright: (c) 2021 by the authors. Licensee MDPI, Basel, Switzerland. This article is an open access article distributed under the terms and conditions of the Creative Commons Attribution (CC BY) license (https:// creativecommons.org/licenses/by/ $4.0 /)$.

\begin{abstract}
The transformation for sustainability requires a paradigm shift towards systems thinking and interdisciplinary collaboration, which entails, above all, a process of cultural change affecting individual mindsets, organizations and society as a whole. Sustainability in higher education institutions (HEIs) has been a recurrent research field in the past decades. However, little attention has been paid to the processes of internal and cultural change and, in particular, to the first steps to prepare academic communities for change. Understanding "readiness for change" as a core organizational competency to overcome continuous environmental changes and considering the diluted hierarchy at HEIs, this article proposes the adoption of dialogical and developmental approaches in a single action case, the SDGs Seminars at the Universidad Politécnica de Madrid. This methodology was used to diagnose organizational and individual readiness for change considering cognitive, affective and behavioural components, and to identify consequences in organizational structures and culture. Our findings reveal that reframing dialogical spaces in HEIs to experience a collaborative and sustainability culture can unlock change, breaking down organizational silos, reducing resistances and engaging academic communities in the cocreation of institutional strategies. Furthermore, the case suggests that acting at the group level has impacts both on the individual and institutional levels.
\end{abstract}

Keywords: readiness for change; higher education; academic culture; collaboration; dialogical; developmental; conversations; transformation; sustainable development goals (SDGs)

\section{Introduction}

The 2030 Agenda for Sustainable Development [1] requires a paradigm shift towards systems thinking, collaboration and interdisciplinarity [2]. This transformation entails, above all, a process of cultural change which affects individual mindsets, organizations and society as a whole [3-5].

Higher education institutions (HEIs) are not an exception and should transform their organizational structure, culture and communication practices in order to overcome disciplinary and sectoral boundaries [2,6]. In fact, their highly fragmented and monodisciplinary structures inherited from the 19th century, as well as a conservative and competitive culture which encourages individualism, hierarchy, incrementalism, bureaucracy and marketoriented strategies [7-11], hinder internal and external collaborative potential [12,13]. As a consequence, their response to societal needs is slowed down [14]. 
HEIs' transformation is particularly relevant given their critical role in the achievement of Sustainable Development Goals (SDGs) $[1,15]$. As institutions that catalyse culture, knowledge and innovation, HEIs have the potential to become change agents for sustainability [16-19]. Furthermore, they are in a position to support almost every SDG [20] through their five interlinked traditional dimensions, namely education; research; organizational and campus operations; community outreach [3]; and assessment and reporting [21]. However, most HEIs focus on SDG 4 "Quality Education", particularly education for sustainability and campus greening [22,23], and disregard holistic strategies [24-27]. Given the interconnected nature of the SDGs' challenges, this holistic approach is essential to achieve internal organizational changes, both structural and behavioural [28-31], as well as to foster multi-stakeholder collaboration [32].

Despite the fact that the number of publications on sustainability in HEIs illustrates the increasing relevance of this growing field of study, processes of cultural change in HEIs are still under-researched $[4,33]$. The purpose of this investigation is to address this research gap by adopting an action case approach to illustrate the first steps to build up momentum in an HEI towards transforming its organization and culture to better address sustainability challenges, taking a readiness for change lens [34]. Change has been often understood as a dialectical and one-time process, where managers and change agents need to persuade organization members that the change they are proposing is necessary and appropriate [34-37]. However, given the diluted hierarchy at HEIs that enables faculty and researchers to display a strong agency [4] and the complexity of transforming the organizational culture towards sustainability, this article explores the adoption of a dialogical and developmental approach.

Using the Universidad Politécnica de Madrid as a case study, its SDGs Seminars [38] have been explored as an example of internal context enablers [37] that promote and sustain a dialogical, developmental and holistic process to prepare the faculty and research community for change. This paper intends to address the following question: How can a holistic approach be adopted to initiate a cultural change process aimed at faculty and the research community in an HEI, in order to foster its contribution to the achievement of the SDGs?

This article is organized into four main sections: Section 2 develops a theoretical overview focusing on the organizational challenges for HEIs to engage with the SDGs and the organizational change frameworks used in the case study. Section 3 presents the research methodology and succinctly describes the case study context, while Section 4 synthesizes its main results from an organizational perspective. Finally, Section 5 discusses the findings, emphasizing the aspects that could be more easily replicated in other HEIs, including some opportunities for further research.

\section{Theoretical Framework}

\subsection{The Need for Change towards Sustainability in HEIs}

Sustainability is a complex, multidimensional and dynamic concept, increasingly understood both as a process of cultural change [3-5] and as a social movement [39]. The complexity and interdependence of the challenges outlined in the SDGs require a paradigm shift, where cooperation and collaboration should play a significant role, as evidenced by SDG 17 [1].

HEIs are particularly key players in promoting transformational contexts in favour of the SDGs. Several reasons may explain their relevant role: they are locally rooted and globally connected [17]; they are situated in an interdependent and changing ecosystem [40]; they are perceived as neutral, free and safe spaces [41]; they are able to gather a diverse critical mass of individuals [26,33,42]; and finally, they are recognized as common partner institutions for the public sector, with local responsibilities and pursuing social and public interests $[27,43,44]$. Furthermore, despite the strong hierarchy that characterizes the academic ladder, power is perceived to be located at all university levels (students, staff, 
faculty, associations, etc.) [4]. Thus, individuals and groups at the top, middle or bottom can act as change agents $[4,33]$.

However, as long-standing institutions, universities have remained very conservative. Still current Newtonian and Cartesian mental models foster reductionist thinking, mechanistic interpretations, repetition, incrementalism, individualism and competitiveness [11]. As a consequence, HEIs are usually very slow in responding to societal needs [18,22]. There is an international consensus that universities need to change to become sustainable organizations, that is, both achieving sustainability internally and leading society's sustainable development [23]. It should be noted that the former is a sine qua non condition for the latter. Additionally, reaching internal sustainability requires going beyond campus greening, incorporating sustainable development values in education, research, operation and community outreach in order to break down the structural constraints of the prevailing traditional systems [23].

In fact, since the 19th century, HEIs have tended to increasingly fragment their structures into highly specialized and disconnected departments [7,8]. In practice, this means that the departmental budget cannot be used to finance complex activities which affect different departments, employees often do not know each other and there is a lack of feedback and information sharing between different areas, among other issues. This siloed approach makes it very difficult to collaborate even within a specific organization, undermining the transformational potential of HEIs. This problem, although emphasized in HEIs, is affecting modern societies in general where the human capacity to cooperate, much wider and complex than institutions allow, is being weakened [31,45,46]. As cooperation is a developmental resource that represents a useful social competency to live in a complex world, a repair effort should be undertaken to establish an organizational culture that enables collaboration, both within and beyond the institution $[6,45]$. In this path of change, collaboration represents at once the result and a characteristic of the process. Widely recognized as a driver for organizational change [6], collaboration enables silo breakdown, creativity, participation, sense of purpose and ownership in the construction of a shared vision $[33,47,48]$.

\subsection{Organizational Change in HEIs}

Although sustainability in HEIs has emerged as a new research field in recent decades, little attention has been paid to structural and cultural change processes towards increasing collaboration, especially those involving the faculty and research community $[4,12,33]$. According to Brinkhurst et al. (2011) [33], "the greatest potential for long-term change comes from active intrapreneurship by faculty and staff" (p. 351), considered as the institutional "middle".

When introducing change in an organization, authors typically identify three phases that can overlap in a continuous process: readiness, adoption and institutionalization [36]. The literature highlights that change success is dependent on a certain degree of readiness for change [34], that is, the extent to which an individual, a group or the organization as a whole is cognitively and emotionally disposed to accept and undertake a particular change $[34,37]$. Adoption is the experimental period in which the change is implemented but could still be rejected, while institutionalization refers to the phase in which changes become the norm [36].

However, more recent approaches define readiness as a desirable constant state in the current complex and dynamic world, a core individual and organizational competency to overcome continuous environmental changes [49]. In this constant state of readiness, the boundaries between the different phases of change become blurred so that the progress towards adoption and institutionalization overlap the readiness phase. Thus, change is understood as an iterative trial and error process, from which the organization can learn to improve the next iteration. By doing so, organizations evolve towards fluid models of learning and adaptation that allow them to become more resilient to internal and contextual changes $[50,51]$. The so-called "learning organizations", defined as places "where people 
are continually learning how to learn together" [50] (p. 3), focus on collective problem solving using systems thinking methodologies in order to expand creativity and patterns of thinking and, at least to some extent, to reach this continuous state of readiness for change. This interpretation of the readiness phenomenon strongly resonates with developmental approaches, often used in organizational development contexts as a way to support adaptive learning in complex and emergent initiatives [52]. Developmental approaches are defined as dynamic, long term, on-going processes of continuous improvement and intentional change where both the path and the destination are evolving [53-55].

Therefore, in addition to diagnosing the readiness level, any change strategy may include a process to enhance it at the individual, group and organizational levels [49]. Based on Wang et al. (2020) [40], system readiness for change in this study is defined as the interaction and achievement of individual (professors and researchers), group (research community, research group, department, etc.) and organizational (HEI) readiness for change.

As transformation towards sustainability in HEIs implies radical organizational innovations in comparison with the current operational system [21], it is not unexpected that different blocking mechanisms arise during a change process, both within individuals and from the context $[56,57]$. Some of the reasons that may explain the resistances to engage with sustainability in HEIs are: the lack of knowledge and awareness of sustainable development, often considered radical or a passing trend; the lack of specific staff to lead the process; the perceived threat to the academic credibility of professors and researchers; or time and budget constraints, among others [58]. Recurrently used in this research field as an explanation for change failure, resistance to change has been traditionally envisioned in terms of conflict between managers (change agents) and employees (change recipients), adopting a black-and-white approach $[59,60]$. More recent studies go back to Lewin's initial conceptualization as a systemic phenomenon [56] defining it as a subjective, complex and three-dimensional construct which comprises affective (How does one feel about a particular change?), cognitive (What does one think about this change?) and behavioural (How does one act in response to this change?) components [61-63]. Nevertheless, even in these cases, resistance to change is seen as a negative attitude towards change. As an exception, Ford and Ford [59,60] propose to adopt a more balanced view, both as an asset and a liability. These authors suggest that resistance is a sort of energy that can be channelled to strengthen the process of change, a kind of engagement which provides valuable information to flesh out the purpose and the change itself, clarify objectives and strategies and build participation [60]. In addition, some authors suggest that these changes should be incorporated gradually as the result of a combination of top-down and bottom-up initiatives $[6,21,42]$.

\subsection{A Dialogical Approach to Organizational Change}

Although the significance of communication in organizational readiness for change is widely accepted $[36,37,64-67]$, change has been often understood as a top-down and dialectical process [33-35], where managers and change agents need to persuade organization members that the change they are proposing is necessary and appropriate through a consistent change message [36]. Nevertheless, empirical studies indicate that participation is particularly key to enhancing employees' sense of agency and change-supportive behaviours [68-71]. The latest research distances from the romantic perspective of leadership [72], breaking the long-standing "leader-follower" dichotomy [73,74]. Even though the interdependency between leaders and followers is acknowledged, their relationship is recognized to be defined by dynamic interpersonal processes [73] deeply conditioned by the organizational culture and the cultural context $[75,76]$. Traditional approaches have typically focused on individuals' perceptions. Nevertheless, the collective behaviour and the interpersonal and social dynamics play a significant role in actively engaging employees in a change process $[34,71]$. 
For all these reasons, this article intends to overcome the dualistic perspective of agents and recipients of change, adopting a dialogical approach. Focusing on group level interaction spaces as places of mediation between top-down and bottom-up perspectives, organizational and individual readiness for change can be connected (Figure 1). Participation, communication and leadership processes take place in these collective spaces, understood as internal context enablers for change [37].

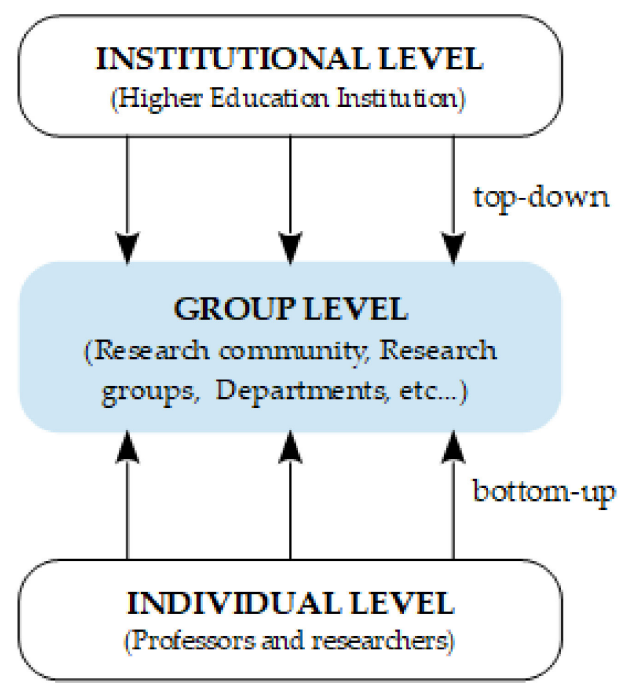

Figure 1. Convergence of institutional and individual levels in an intermediate space in a higher education institution. Source: the authors.

This dialogical approach is consistent with the ideas defended by scholars such as Ford and Ford [66] or Grant and Marshak (2011) [67], which suggest that the management of change is the management of conversations. These authors consider that organizational culture is the result of diverse and interconnected, written and verbal micro-conversations. Communication is thus suggested to be the generative mechanism of change, rather than a tool to leverage change $[66,67]$.

Specifically, four types of conversation for organizational change are distinguished [66]:

1. The initiative conversation, which is a purpose statement to focus listeners' attention on what change promoters think that could or should be done as a response to a crisis or to anticipated challenges;

2. The conversations for understanding, which aim to agree upon the change conditions of satisfaction and involve organization members by creating a shared context, examining the assumptions and developing a common language among participants;

3. The conversations for action, where plans, timelines and accountabilities are developed; 4. The conversations for closure, held when a stage of change is completed or when the process comes to an end, in order to celebrate progress and discuss the continuity path.

Even if these types of conversations set a general direction from (1) to (4), this process is not usually linear, as conversations are dynamic phenomena.

Coming back to HEIs, seminars are one of the most popular conversational spaces for the research community. Their typical purpose is to reach a cooperative conclusion about a topic related to all participants' backgrounds through the intensive and horizontal exchange of knowledge and experiences [77]. Conferences and seminars are considered particularly relevant in academic contexts as they provide a space for international visibility and networking, as well as the opportunity to share learnings, staying up to date with the latest research, presenting and defending one's work or receiving useful feedback to drive further research [78-80]. Despite the fact that much has been written in terms of environmental sustainability in academic conversational spaces [79-85], the literature disregards its cultural and transformative dimensions. Thus, this paper aims to analyse how seminars and conferences, as common mechanisms of interaction, participation and 
communication in academic contexts, could be dialogical spaces to enhance readiness for change in HEIs.

\section{Research Approach}

\subsection{Action Case Methodology}

This investigation is approached through an action case methodology, which is a hybrid of action research — directed to deliver changes in practice — and case study—focusing on observing, understanding and interpreting (Figure 2) [86].

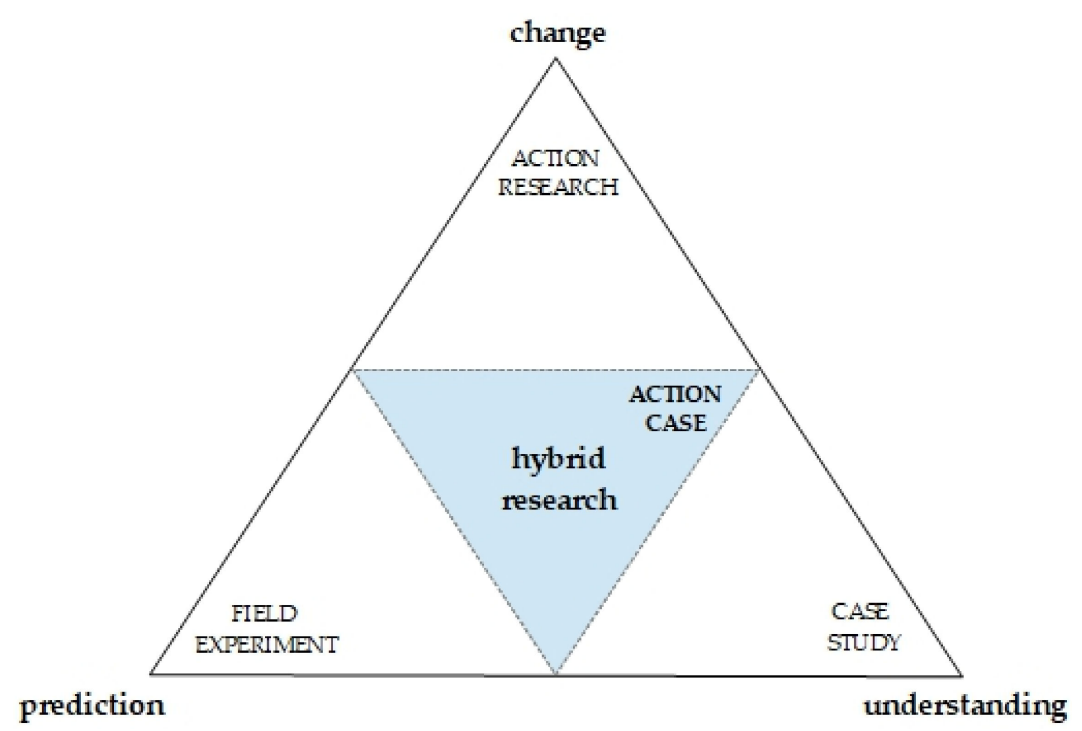

Figure 2. Action case as a mixed methodology between action research and case study. Source: Adapted by the authors from Braa and Vidgen, 1999 [86].

Both methodologies serve descriptive purposes and play an important role in theory testing and building within the context of practice itself [86-88]. On the one hand, case studies are typically used to "investigate a contemporary phenomenon in depth and within its real-life context, especially when the boundaries between phenomenon and context are not clearly evident" [89] (p. 13). They are particularly applicable when the research question can be formulated in terms of "how" or "why", as they offer rich empirical descriptions based on a variety of data sources $[87,90,91]$. This methodology has been extensively used in multiple fields, including organizational theory [92], sustainability [41,93,94] and education [95]. Case studies have been specifically applied to the analysis of sustainability-related organizational change processes [30], particularly in a higher education context [4], and collaborative initiatives, because of their multi-disciplinary and cross-cutting nature [96]. On the other hand, action research is rooted in organizational development and social change $[56,86,97]$. This second methodology intends to understand and interpret social practices in order to change and improve them through a five-phase cycle (diagnosing, action planning, action taking, evaluating and learning) that shapes a systematic learning process $[53,55,98,99]$.

Action cases are particularly well-suited to organizational contexts, when full action research is not appropriate due to organizational constraints or the nature of the topic to be investigated [86]. In this type of research, the researcher is not a mere observer but an agent of change who engages in cogenerating "actionable scientific knowledge" [100]. The action case was conducted between October 2018 and March 2020, when the COVID-19 pandemic slowed the process down and forced us to reframe the strategy in order to adapt it to social distancing and virtuality. However, it should be noted that the programme is still running while this article is being written $[38,101]$. The analysis regarding organizational readiness for change was added to the study at a later stage, between January and June 2021, and it included external researchers. 
Another important feature of the case study methodology is the use of multiple sources of evidence that can be triangulated in order to better substantiate findings [87]. The case was built using a variety of sources of information: key documents associated with the initiative (Table A1), written and recorded material coming from the different activities organized (Table A2), participant surveys (Table A3) and other meta-evaluation material, such as focus group minutes and reports (Table A4), gathered by one of the researchers engaged in participant observation. During the development of the case, a monitoring and evaluation plan based on developmental evaluation [53-55] structured the data collection. This kind of plan establishes initial methodologies for a flexible, evolutionary, iterative and continuous design of the investigation [54,91]. Appendix A compiles further information about the sources of evidence.

The information was analysed using coded-based content analysis techniques [102], which enabled us to identify cross-sectional themes. A crucial step in content analysis is codifying the text (or content) of a piece into various groups or categories depending on selected criteria. In this case, the codes were established "a priori" from the theoretical frameworks explained above, focusing on the analysis of readiness for change through:

1. The five change message domains, namely discrepancy, appropriateness, efficacy, principal support and personal valence [36];

2. The participants' perception of change $[57,103]$, considering cognitive (belief in the need for change, in one's or the organization's capability to undertake change and in positive individual outcomes) and affective components, such as hope, optimism, excitement, relaxation, etc. [37].

\subsection{The Case of the SDGs Seminars at the Universidad Politécnica de Madrid}

3.2.1. Justification for the Selection of the Case

The seminars "Technology and Innovation for the Sustainable Development Goals" (SDGs Seminars) are a programme of gatherings established in 2018 at the Universidad Politécnica de Madrid (UPM) as part of a long term strategy to increase its scientific and sustainability impact $[38,104]$. The programme was born as a top-down strategy, promoted by internal financing of the Vice-Rector's Office for Research, Innovation and Doctorate [104]. It was conceived by a group of nine professors with a large scientific career and facilitated by the UPM's Innovation and Technology for Development Centre (itdUPM). However, the SDGs Seminars followed a bottom-up approach, designed as a space to listen to the faculty and research community.

The proposal (Table A1) intended to respond to anticipated challenges derived from coming changes in European research and innovation policies $[105,106]$ and to the expected contribution of HEIs to the SDGs [20]. In addition, the strategy was based on the theory of change, inspired by the 2030 Agenda and shared by different European organisms, which considers that more diverse and connected research and innovation would accelerate learning and, thus, transformation towards a sustainable system [107]. Hence, the SDGs Seminars focused on the faculty and research community and were conceived as a device to foster an organizational change process. Their main goals were: breaking silos between disciplines, academic communities and other structures; supporting cross-disciplinary and multi-stakeholder collaboration; strengthening a culture of innovation for sustainability through new projects focused on global issues; and boosting partnerships with public administrations, the private sector and civil society. The case was acknowledged as a successful process due to, among other aspects, the high recorded and diverse participation.

The case was accurately selected so that it served as an "extreme case" [87,108]. These are defined as cases of particular research interest, in which process dynamics are transparently observed [108]. The SDGs Seminars case provides analytical material of particular ambition, richness and interest in relation to the research aims, due to its strategic nature, its institutional-wide scope and its extension in terms of time. The study hence allows a longitudinal analysis of all associated outcomes since the creation of the programme. 


\subsubsection{Context of the Case}

It should be pointed out that the UPM is a medium-size technological public university located in the Spanish capital and divided into 4 campuses, 17 schools and 23 research centres. UPM's academic community brings together about 45,000 persons, among which are 40,000 bachelor's, master's and PhD students; 3000 lecturers; and 2000 staff members [109].

Since 2015, the year in which the 2030 Agenda was adopted, UPM has undergone a wide variety of initiatives to become a leading actor for sustainability. Some of them, such as the Sustainability Plan approved in 2018 [110], were promoted by the governing bodies; others, the majority, were driven by academic community members. Even though, in 2018, UPM had already begun its transformation towards sustainability, this university lacked a comprehensive strategy to connect and ensure coherence between all these emerging initiatives.

\section{Results and Discussion}

The following subsections present the main results of the SDGs Seminars programme from October 2018 to March 2020. Special emphasis has been placed in describing the characteristics of this space of conversations for change and its main contributions to the cycle of change.

\subsection{Designing a Safe Space of Conversations for Change in a HEI}

As explained before, increasing HEIs' impact on SDGs requires fostering systems thinking and learning and, thus, interdisciplinary interaction and collaboration [2,107]. Following a learning by doing approach, the strategy intended to create suitable conditions for faculty and researchers to learn how to collaborate by collaborating by means of the alignment of their research to the SDGs. For this to happen, the facilitation team paid particular attention to the design of an innovative, diverse and stimulating space for conversations for change. This intermediate collective room should foster convergence between disciplines, sectors, stakeholders and institutional and individual (or top-down and bottom-up) initiatives. The creation of a productive and continuous dialogue aimed to establish connections, build up new (and unlikely) relationships and generate internal and distributed leadership to catalyse new opportunities.

In the 18 months after the kick-off, 4 series and 16 sessions were held (Table A5) [101]. These combined institutional declarations, workshops and inspiring dialogues between outstanding figures from academic, private, public and civil sectors. This subsection provides a detailed description of the main characteristics and findings of this space of conversations for change.

\subsubsection{A Typology of Conversations for Change in HEIs}

Despite the fact that the literature disregards cultural and transformative dimensions of academic conversational spaces, a seminar programme was a priori considered as an appropriate instrument to initiate the transformation of the academic culture. This traditional space of interaction, participation and communication in HEIs [78-81] is defined by practices and values which are consistent with the pursued change, such as interdisciplinary dialogue, horizontality and search of collaborative solutions [77].

To boost the seminars' capacity to transform academic culture, their design was approached as a relational challenge instead of the usual logistical perspective [111]. Following Ford and Ford (1995) [66], the dialogue-based change process was designed as the iteration of initiative, understanding, action and closure conversations. Specifically, five types of conversations were designed (Figure 3):

1. Opening conversations (initiative): held at the beginning of each academic course,

they aim to demonstrate institutional support and establish a desired future vision to persuade the faculty and research community members that change is needed. 
2. Conversations for connection (understanding type 1): marketplace of initiatives, whose goal is to stimulate interaction and to reach a common understanding between researchers of different disciplines around a cross-cutting topic.

3. Inspirational conversations (understanding type 2): they aim to broaden researchers' views (scientific, political, economic and social) through a dialogue between scientists and practitioners from different sectors, to build a common language and to make new questions arise which can only be solved from the interaction between different disciplines and stakeholders.

4. Conversations for action: cocreation workshops, whose purpose is to listen to the faculty and research community and to concretize collective and interdisciplinary actions, based on current research interests, to transform UPM into a sustainable university.

5. Conversations for closure: taking place at the end of a particular stage (i.e., the end of the school year) or when the process is considered to come to an end, this kind of conversation intends to summarize, justify and acknowledge the results of the process in a celebration context. This also may include dialogues to discuss continuity and new possibilities.

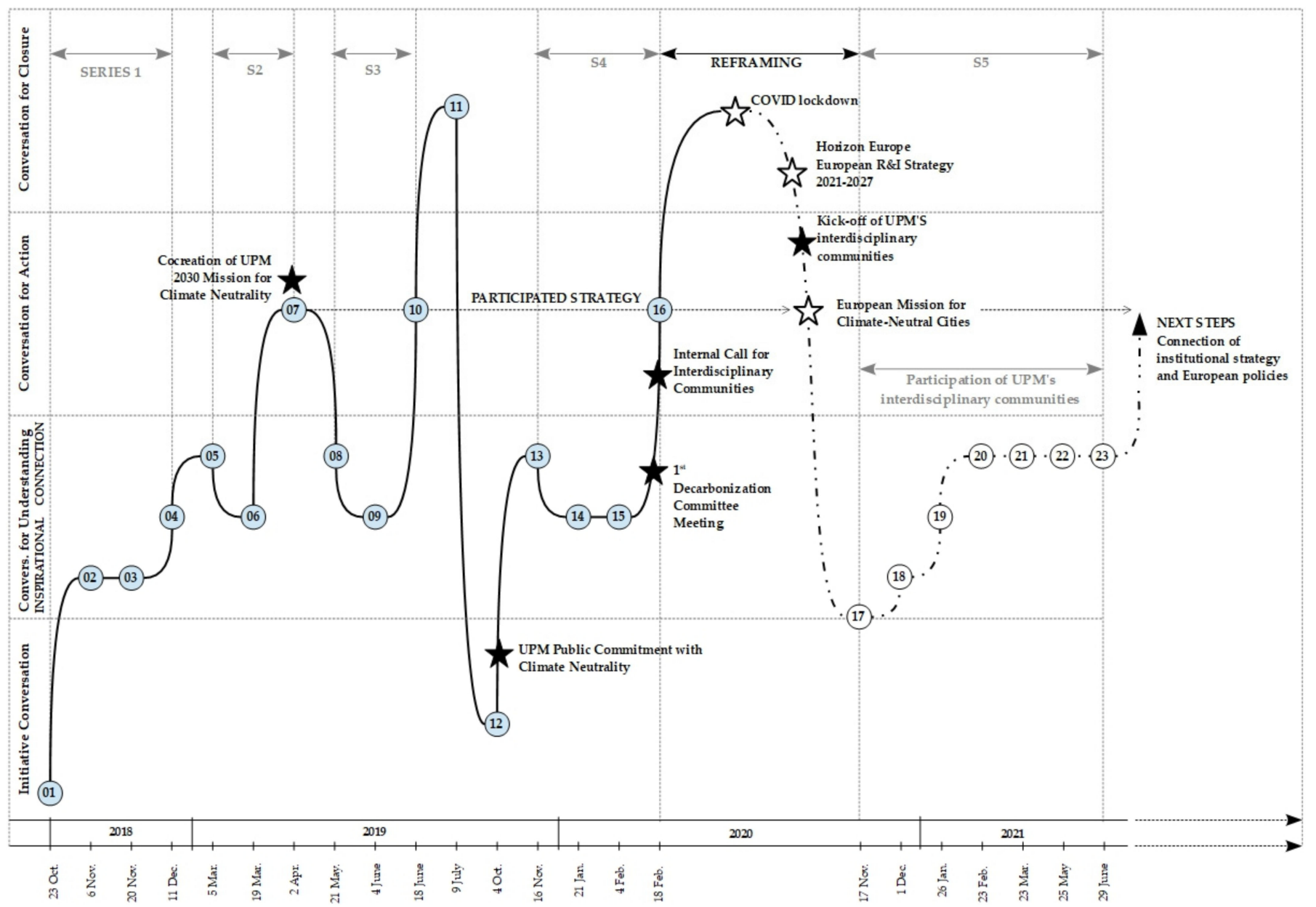

Figure 3. Diagram of the process of conversations for change. Source: the authors.

The iteration of at least three seminars, including different types of conversations, framed the seminar series. Two categories were distinguished: (1) opening and (2) thematic. The opening series was called "Introducing the SDGs", whose main goals were to make researchers aware of the relevance of the SDGs and build up a common understanding of the role that UPM could play in the transformation towards sustainability. The thematic series focused on cross-cutting topics related to the SDGs. They aimed to connect professors and researchers and identify leadership, as a first step towards building thematic 
interdisciplinary research and knowledge communities. It is noteworthy to mention that the topics were chosen in response to faculty and researchers' interests identified during the opening series, namely: "Energy Transition and Climate Change", "Circular Economy and New Materials" and "Sustainable Natural Resource Management".

Altogether an opening series, three thematic series, two initiative conversations, ten conversations for understanding, three conversations for action and a conversation for closure were organized until March 2020 (Table A5). The flow of conversations is summarized in Figure 3. After this date, the lockdown caused by the COVID-19 pandemic forced the redesign of the frequency and the formats to adapt the process to social distancing. Nevertheless, as the programme was solidly established, these changes were positively embraced by the faculty and research community, and six virtual sessions were organized until the writing of this article [101].

\subsubsection{Conditions Enabling Participation, Diversity and Connection}

Following the "leaving no one behind" principle of the 2030 Agenda, special attention was given to the conditions that make this space inclusive and diverse. The process was considered a success in terms of participation. More than 1000 attendees were part of the programme (Table A5), $80 \%$ of which belonged to UPM's faculty and research community and $49 \%$ of which were women, a very high figure considering that women only represent the $24.7 \%$ of the UPM's faculty and research community [112]. It is worth noting that all campuses, schools, disciplines and research centres participated in the process to some extent. In particular, participants belonged to 140 research groups (about $67 \%$ of UPM's research groups), 18 research centres and 17 schools. Regarding the speakers, 17 high position representatives from public, private and civil organizations as well as 59 members of UPM's research community (PhDs, professors and researchers from different academic ladder positions) participated as panellists in the dialogues. These figures and those in Table 1 evince that the process was very diverse in terms of gender, disciplines and stakeholders. Furthermore, the space attracted the interest of other groups (Table 2), both internal (students and staff) and external (i.e., faculty and researchers from other HEIs, public servants, representatives from the private sector, etc.). As a consequence, the space was progressively open beyond the faculty and research community.

Table 1. Distribution of participants according to the community to which they belong. Source: the authors, from the assistance database.

\begin{tabular}{cc}
\hline Community & $\%$ Participants \\
\hline Faculty and Researchers & $66.6 \%$ \\
\hline Professor & $7.7 \%$ \\
\hline Associate Professor & $21.8 \%$ \\
\hline Assistant Professor & $4.7 \%$ \\
\hline Adjunct Professor & $2,2 \%$ \\
\hline Emeritus Professor & $1.9 \%$ \\
\hline Research Associate & $17.0 \%$ \\
\hline Research Fellow & $2.2 \%$ \\
\hline Other Positions & $9.1 \%$ \\
\hline Students & $16.3 \%$ \\
\hline Bachelor & $4.3 \%$ \\
\hline Master & $3.8 \%$ \\
\hline PhD & $8.2 \%$ \\
\hline Staff & $2.5 \%$ \\
\hline Non UPM & $14.6 \%$ \\
\hline
\end{tabular}


Table 2. Researchers' attitudes towards SDGs. Results of the survey launched in sessions 1, 2 and 3. Source: Annual Report 2018.

\begin{tabular}{ccccc}
\hline Topic & Very Low & Low & High & Very High \\
\hline Knowledge of the SDGs & $12.9 \%$ & $24.4 \%$ & $16.2 \%$ & $39.8 \%$ \\
\hline $\begin{array}{c}\text { Confidence in the probability of } \\
\text { achieving SDGs }\end{array}$ & $21.0 \%$ & $47.4 \%$ & $22.4 \%$ & $1.1 \%$ \\
\hline $\begin{array}{c}\text { Awareness of the relevance of } \\
\text { SDGs for their research field }\end{array}$ & $1.5 \%$ & $8.1 \%$ & $23.2 \%$ & $59,6 \%$ \\
\hline
\end{tabular}

For this to happen, the role of the facilitation team was relevant to foster communication and encourage attendance at the sessions. Four strategies are considered key for good performance in terms of participation and diversity: (1) the itinerancy across different schools and campuses, selected in order to facilitate the attendance of professors and researchers whose work was close to the cross-cutting topic of each session; (2) a distributed communication strategy, counting on UPM, schools and research centres' communication offices, but also using word of mouth as one of the most powerful tools; (3) detailed monitoring, allowing the performance to be tracked in real time and, thus, informed decisions to be made (i.e., related to the communication strategy); and (4) the streaming and recording of the sessions for their publication on YouTube [113], aiming to facilitate virtual attendance and results sharing with those who could not participate in real time. In this regard, it is worth noting that some of the videos have received more than 500 views in the space of a few days [113] and that this experience was considered absolutely crucial for the survival of the programme during the COVID-19 lockdown.

However, despite its importance for the success of the process, the simple assistance was not considered sufficient to reach readiness for change. Two further aspects were considered essential to weave new collaboration relationships: the quality of the interaction and the number of interconnection opportunities.

According to the quality of the interaction, the typologies described in 4.1.1 always included a space for exchange but responded to different interaction levels. They included strategies such as question times, short speeches, group dynamics, surveys and an app to send and vote on questions. In particular, during inspirational sessions, interaction was medium-low and bidirectional, through the exchange of questions, answers and remarks between speakers and participants for at least 15 of the 90 min of the session. Furthermore, participants were invited to share their questions, from the beginning of the session, through a mobile app called Slido [114], where they could also vote on other participants' questions. In contrast, connection sessions had a medium-high interaction level, as they included several $3 \mathrm{~min}$ speeches prepared by researchers working on subjects related to the cross-cutting topic of the series, group dynamics aiming to find connections between current research lines and both the SDGs and complementary research studies and finally, at the end of the session, an informal coffee space to foster networking between participants. The most interactive sessions were the conversations for action, workshops where researchers from different positions, university staff and managers could discuss future action lines in a horizontal and safe dialogue. At the end of every session, an anonymous survey was launched to measure participants' degree of satisfaction (interest, usefulness for their research and efficacy of the session to transform university culture), including a space for suggestions.

In fact, the space provided the opportunity for faculty and researchers to deal with thoughts and emotions caused by the change process. It was thus very important to take special care of the context details, creating a trust atmosphere and promoting a constructive and relaxed tone of conversation. In addition to this, although the use of both Spanish and English was envisaged depending on the needs of the participants, Spanish was the language actually preferred by panellists and attendants. Additionally, the characteristics of the physical space were certainly very relevant for the quality of the interaction. However, 
the observation revealed that HEI spaces are deeply conditioned by hierarchical behaviour patterns [111], generally dividing those who know and those who learn. The facilitation team overcame the lack of horizontal conversational spaces by experimenting on different furniture and lighting layouts (Figure A1) and ensuring distributed participation, especially providing equal opportunities to speak for young faculty and researchers.

Concerning interconnection strategies, different group dynamics were developed to foster networking and concretize collaboration opportunities. Particularly relevant was the visualization of connections between research lines and SDGs (Figure 4), which offered a new and non-disciplinary viewpoint for collaboration and, what is probably most important, provided an exciting direction (a target of the SDGs) to join forces and start working together.

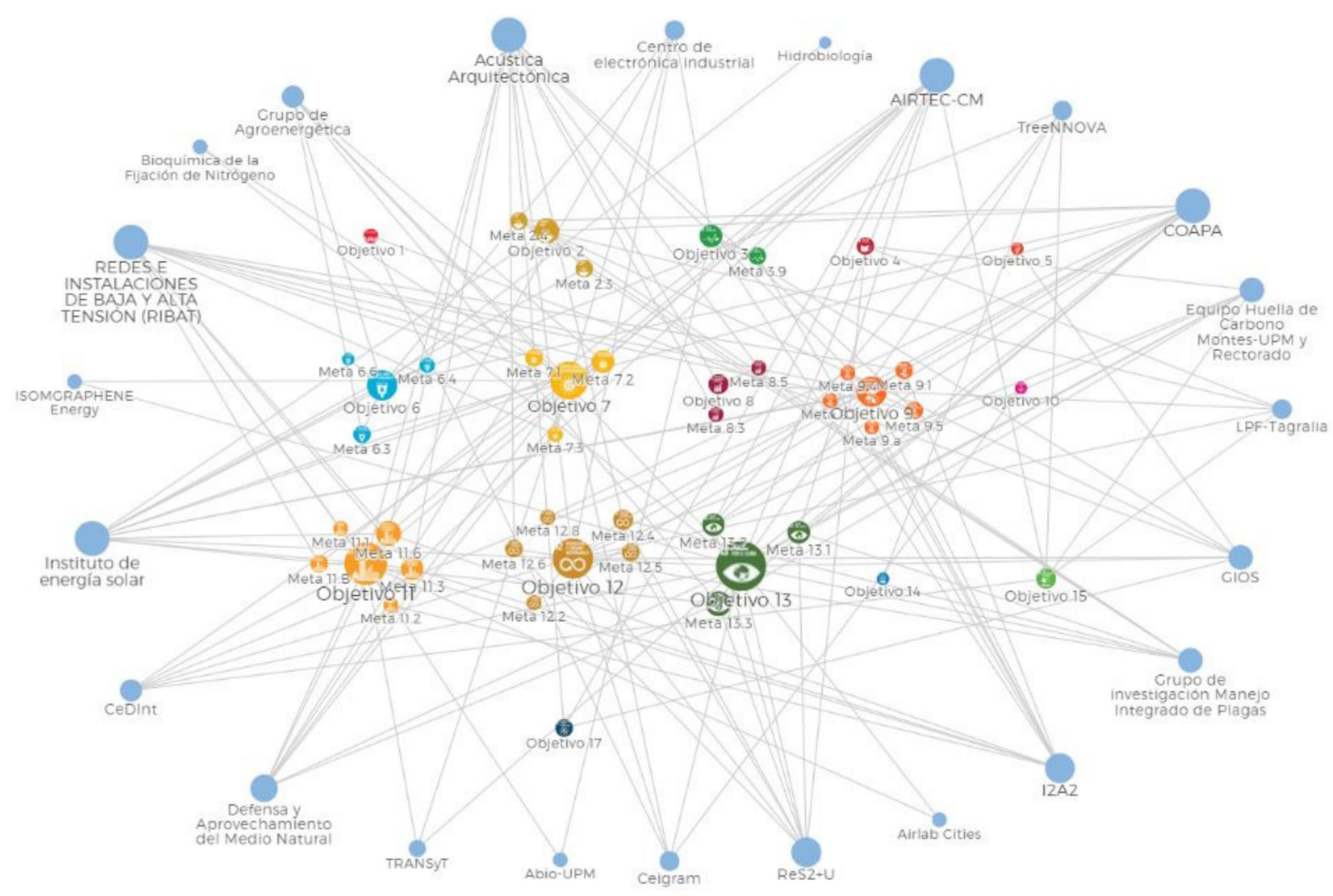

Figure 4. Example of diagram of relationships between the research groups participating in a thematic series and the targets of the SDGs. Source: Universidad Politécnica de Madrid. SDGs Seminars Annual Report 2019.

An unexpected result was the role of the formal conversations as catalysts of informal dialogues, where the new relationships effectively evolve and strengthen [45]. For instance, the observation revealed that lobbies, corridors and cafeterias around the venue should also be considered as spaces of conversations for change. Future research can explore the contribution of informal spaces to readiness for change enhancement.

\subsubsection{A Developmental Model to Sustain the Process over Time}

Once the conversation spaces were designed from a relational viewpoint, the challenge was to sustain the process over time. As rituals are considered to facilitate meaningful cooperation in working, political and community life [45], the creation of a gathering ritual seemed to be decisive for success. The results suggest that three factors were particularly pivotal: (1) the establishment of a routine (on Tuesdays, from 2:00 to 3:30 p.m., every two weeks or at least once a month); (2) the repetitive use of decoration elements (i.e., an SDG wheel); and (3) a recognizable format (i.e., Vice-Rector's opening, participation rules, questions and answers app, satisfaction ending survey, etc.).

Furthermore, the process followed a developmental rationality [53-55], so that the content and form of each conversation was shaped according to the results of the previous 
session and leveraging context opportunities (i.e., changes in public policies, coming funding calls, etc.). Adapting the process to the real context contributed to the fact that faculty and researchers perceived it as a useful space both for their own work and for organizational transformation.

The adequate combination of flexibility and repetition was considered critical. The coherence between the two strategies was achieved through the construction of a unifying narrative (an evolving change message nourished by conversations), which was shared with the academic community in every session, as well as by other mechanisms such as videos, posts, newsletters, social media, etc. Ultimately, a continuous and developmental communication strategy was established, which registers and informs every step of the process and facilitates the incorporation of new participants. To legitimise the evolving change message, every session counted on a UPM representative (i.e., a Vice-Rector, a School Dean, etc.).

\subsection{A Space Supporting a Change-Oriented Process}

Once the main characteristics of this academic space of conversations for change are explained, it is important to describe how it served the change-oriented process. Considering the different stages in the cycle of change, there are three main purposes: (1) diagnosing readiness for change; (2) defining a participating change strategy; and (3) institutionalizing changes in the organizational structures and culture.

\subsubsection{Diagnosing Faculty and Research Community's Perception of Change}

First of all, following a traditional readiness for change approach, the space served to assess faculty and researchers' perceptions on the specific proposed change $[57,103]$ (a predetermined direction of change, namely to foster a collaborative culture in order to cocreate interdisciplinary and multi-stakeholder solutions for SDGs), considering both cognitive and affective components [37]. For this purpose, three sessions were organized on different campuses, where live surveys and focus groups were employed as data collection methodologies. On the whole, results revealed a positive and enthusiastic attitude towards change even if some blocking narratives were detected, which were considered very useful to provide feedback and develop a consistent change message.

Firstly, faculty and researchers' perception on SDGs was evaluated during sessions 1, 2 and 3 through a short online survey (Table A6), launched after a lecture and whose results were discussed in real time. In particular, the dimensions assessed included researchers' attitudes towards these goals in terms of knowledge, confidence in their feasibility and relevance for their research field. Additionally, they were to identify to which SDGs they are contributing through their current research and teaching. A total of 271 researchers $(10 \%$ of the research community) completed the survey, $48.8 \%$ of which were women. It should be noted that the respondents' positions in the academic career ladder were very diverse: $6.9 \%$ were Professors, 13.8\% Associate Professors, 8.4\% PhDs and 18.2\% Research Associates, among others. The main results are presented in Table 2 and summarized hereafter:

- There was a lack of knowledge of the SDGs among the research community, especially considering that the respondents, as they attended the session, had already shown some interest in sustainability and SDGs.

- There was a lack of confidence in the probability of achieving them. These pessimistic or sceptical attitudes, which could represent resistance, are natural in scientists and could be explained by the fact that there is no empirical evidence of the accomplishment of the goals.

- Researchers felt aware of the relevance of SDGs for their fields.

- UPM's research covers a large range of goals, among which SDGs 4, 7, 9, 11, 12 and 13 should be highlighted.

In short, the results revealed that UPM's faculty and research community are quite aware of the relevance of the SDGs and could contribute to a wide range of them, highlighting those related to education and technology. Nevertheless, there was still a lack of 
knowledge and confidence in achieving these goals. Hence, this first diagnosis reflects the need for an appropriate space for training and understanding.

A second live survey during sessions 2 and 3 assessed faculty and researchers' perceptions on interdisciplinary and multi-stakeholder collaboration according to three levels of analysis: individual, research group and organization (Table A7). This second questionnaire also aimed to understand to what extent the current context enabled collaboration. A total of 112 researchers attended these workshops, $57.9 \%$ of which were women. Participation was very diverse in terms of age and professional position. In short, participants suggested that change was needed ("discrepancy" [36]) because:

- Academic context is not encouraging interdisciplinary and multi-stakeholder collaboration (according to $78 \%$ of the respondents). Furthermore, knowledge transfer to society in non-peer-reviewed formats is seen as a loss of time (58\%), due to their low curricular profitability.

- Research groups are moderately diverse, and relationships within are not very hierarchical (68\%).

- Even if collaboration between disciplines is increasingly common (61\%), it still takes place between peers (64\%).

- Researchers do not usually assess the social and economic impact of their investigation $(83 \%)$.

Furthermore, two group conversations took place at the end of sessions 2 and 3 in order to assess researchers' perception of UPM's transformation. The majority of the participants agreed that this cultural change towards SDGs was also appropriate, arguing that:

- SDGs represent a unique opportunity to internally transform UPM towards a more sustainable and collaborative university, as they provide a common framework and language for all disciplines that could make it easier to work together.

- SDGs can also help connect individual incentives with organizational and global interests. Thus, they could improve both internal relationships between research groups, departments and schools and cohesion around the construction of a common project.

- SDGs also benefit international visibility, attracting financial support, since funding institutions were incorporating them as a framework for their competitive calls.

Furthermore, participants also had confidence in UPM's capacity to contribute to SDGs (efficacy), due to the practical and problem-solving orientation of its academic offerings (Engineering, Architecture, Physical Activity and Sports) and research. However, from the participants' points of view, some organizational changes must take place to actually transform UPM's culture:

- Changes in the incentive system (i.e., highly value collaboration, quality and social impact in researchers' curricula, further internal funding to foster interdisciplinary and multi-stakeholder collaboration);

- Changes in relationships within departments and research groups (i.e., reducing hierarchy, involving young researchers in decision making);

- Changes in physical and virtual spaces to enhance communication between academic structures in order to share knowledge, experiences, resources and contacts (i.e., interdisciplinary rooms).

Finally, some participants perceived a lack of institutional support, due to the many bureaucratic barriers hindering collaboration, whereas others appreciated institutional efforts such as the creation of cross-cutting structures or the encouragement for students to include SDGs in their final degree or master's thesis.

These dialogues also allowed for a better understanding of individual and collective narratives. From the emotional point of view, on the whole, results suggest that participants felt hopeful and enthusiastic with the proposed change. Nevertheless, some blocking narratives were identified, such as pessimism (i.e., academic culture, lacking in diversity, strongly hierarchical and typified by a slow and inefficient bureaucracy, is static and unchangeable), fear (i.e., interdisciplinarity is perceived to diminish rigor) and scepticism 
(i.e., "Sustainable development" is seen as an increasingly empty label which risks being used without any change). In particular, young researchers felt invisible and powerless.

Therefore, all these results demonstrate the capacity of the SDGs Seminars to diagnose readiness for change in UPM. In detail, participants' perceptions and narratives were assessed, including cognitive and affective components. The evaluation focused on the five message domains: discrepancy, efficacy, appropriateness, principal support and personal valence [115]. Although the literature highlights the limited evidence of the reliability and validity of readiness assessment instruments [116], this preliminary analysis provided valuable feedback in the form of incentives and resistance to change. These enabled shaping and qualifying the developmental change message and polishing the next steps of the process to enhance readiness for change at the individual, group and organizational levels [49].

\subsubsection{Defining an HEI Participated Strategy towards the SDGs}

Afterwards, the space was used to craft a common purpose at the university level, aiming to position UPM as a relevant actor for sustainability. Thus, the next sessions were devoted to collectively reflect on the current situation of the university, the context opportunities and possible action lines to concretize the proposed direction of change and to enhance its appropriateness. Every conversation counted on a UPM representative in order to guarantee institutional support. The strategy followed three steps: inspiration, connection and action.

Inspiration turned out to be essential to craft a shared vision and create commitment. Inspirational sessions (five throughout the programme) delve into the developmental change message through different stakeholders' perspectives (high level institutional, business and civil sector representatives, municipal staff, researchers from other universities or renowned research centres, etc.). These opinion leaders from both inside and outside HEIs were involved in dialogical conversations where the necessary complementarity between disciplines and sectors to tackle sustainability challenges was showcased.

According to connection, three sessions were organized throughout the process in order to establish new and interdisciplinary relationships between faculty and research community members. Specifically, participants were invited to reflect about partnerships that could strengthen their own contribution to the proposed change. Some questions guided the conversation, concerning:

1. The SDGs approach: What SDGs and targets does my research contribute to? What do its initiatives do to "leave no one behind", the motto of the 2030 Agenda?

2. Interdisciplinary and multi-stakeholder collaboration: How many people and which disciplines and research groups are involved? What external actors collaborate with my research and how do they collaborate?

3. Impact: How can I broaden the focus of my research? What other UPM research groups could become involved? What other external agents could be relevant?

Finally, the conversations for action resulted in three cocreation workshops, one per series, whose main goal was to engage the community in UPM transformation through participation. During these sessions, a reduced and diverse group (less than 50 people) participated in a conversation, pointing to agree on strategic lines to transform UPM campuses, in accordance with their research interests and to be shared with the governing bodies. Particularly useful was the concept of "mission", adopted from the approach of the Italian economist Mariana Mazzucato for European research and innovation [105]. The first conversation permitted collectively adapting this notion to the HEI scale and outlining an initial idea of what UPM's mission for SDGs could look like. The workshops consisted of several group dynamics including guiding questions such as: What mission could we propose? What existing projects have the potential to be tractors for this mission? Which actors could we involve to strengthen the process and guarantee the success? As a result, participants agreed on the mission "Reaching a carbon-free UPM by 2030", which was embraced by the Vice-Rector for Quality and Efficiency, responsible for sustainability in 
UPM campuses. Then, during workshops 2 and 3, participants went in depth into the concretion of action lines to reach this mission. The endorsement of the UPM Declaration on the Occasion of the 2019 United Nations Climate Change Conference in Madrid [117], seven months after the first workshop, reflects the relevance of this process and its impact on UPM policies: "the UPM endorses climate change action in line with the 17 SDGs on the 2030 Agenda, setting itself the interim goal of achieving zero net direct greenhouse gas emissions by 2030 in order to achieve climate neutrality by 2040" [117] (p. 1). Thus, it can be concluded that the "mission" concept can be a catalyst for HEI transformation. Nevertheless, attention should be paid to actually using this concept as a boost for innovation and not as a means to research and teach "as usual".

Concerning faculty and researchers' behaviour during this participatory process, the observation revealed a lack of participation culture. In fact, at the beginning of the process, participants felt quite disconcerted, as they were not used to being consulted for institutional policies. Furthermore, some participants felt quite afraid of participating, being judged or being wrong, as they believed not to have enough information. Others found it very difficult to imagine future scenarios if they are not responding to a call or a fund. However, it must be highlighted that the facilitation team perceived an increasing trust in the programme, resulting in growing levels of participation and interaction. The simple construction of a shared vision that positions UPM as a relevant actor for sustainability was already considered an appealing purpose. Ultimately, researchers acknowledged this conversational space and progressively felt more confident to share their ideas. Therefore, seminar programmes such as SDGs Seminars can be considered internal context enablers for change in HEIs, as they provide spaces for participation, communication and leadership processes and furnish a context for academic communities to learn how to collaborate by collaborating. Such spaces can also contribute to make the HEI evolve towards a more fluid model of learning and adaptation to internal and context changes.

\subsubsection{Evolution of Organizational Culture and Structure Enabling Collaboration and Change}

Finally, it should be noted that enhancing readiness for change had an impact on organizational culture and structures enabling collaboration. The consequences are visible in the collaborative approach of the internal funding calls, in the increasing relationships between academic communities and disciplines, and even in the creation of a new professional profile.

First, the approach of internal funding was influenced by the process, evolving from meritocratic individual calls to an "interdisciplinary community" model, where the evaluation scale grants a higher score to the proposals involving different disciplines and actors and demonstrating a previous collaboration path.

Second, three novel interdisciplinary structures were created and provided with an internal budget through competitive calls, in order to enable collaboration and change:

- The interdisciplinary research communities around cross-cutting topics related to the SDGs [118], three of which were born inside the SDGs Seminars change process (Circular Campus [119], Transition towards an emission-free university [120] and Collaboratory for decarbonization [121]);

- The teaching communities, still in the pipeline, which are a second version of interdisciplinary academic communities that will also include students and professors from different European universities [122];

- The Decarbonization Committee (50 people including researchers, professors and students from different disciplines, staff and institutional decision makers), which was created as a result of the mission proposed by the participants at the SDGs Seminar workshop and whose goal is to concretize a decarbonization strategy [123].

It is worth stressing that all these structures operate in a horizontal, collaborative and dialogical way and that their goals ultimately aim at the SDGs. In fact, the process contributed to creating relationships at an early stage, bringing faculty and researchers 
from different disciplines closer around specific cross-cutting topics. The internal funds enabled the consolidation of these informal groups into formal communities.

Finally, a new professional profile was created: the interdisciplinary community facilitator. His or her role goes beyond the traditional project manager, focusing on deep listening to the community, facilitating internal and external communication and knowledge transfer, identifying opportunities, establishing connections through the design of conversational spaces and innovating in new collaboration models. The evolution and performance of this new academic profile opens future research paths in the field of HEIs organizational transformation.

\section{Discussion}

From a theoretical point of view, this article combines the readiness for change framework [34,36] with dialogical [66,67] and developmental [53-55] approaches in a single case study. On the one hand, although change has been often understood as a dialectical process [35], the diluted hierarchy at HEIs explains the relevance for exploring this phenomenon from a dialogical perspective. On the other hand, more recent studies that define readiness as a desirable constant state (or a core organizational competency) to overcome continuous environmental changes [49] support the adoption of a developmental lens.

The practical blend of approaches provides relevant information about the first steps to enhance readiness for change in an HEI, in order to reach a fluid organizational model [49] and transform this institution into a learning organization [50]. Collaboration, capacity building, pedagogy and systemic policies are considered right drivers for large-scale changes in academic contexts [6]. Considering the current siloed structure and culture at HEIs and that collaboration capabilities cannot be learnt theoretically, universities need to create the conditions for academic communities to experience this form of relationship. The case showcases a lack of horizontal and dialogical spaces in academic contexts that should be supported by further comparative research.

Specifically, this investigation suggests that a seminar programme can be considered an internal context enabler for change [37] in the HEI contexts, since it provides a continuous space for participation, communication and distributed leadership, furnishing a context for academic communities to learn by doing a horizontal, participatory and institutionally committed culture. On the one hand, the creation of a gathering ritual is consistent with the idea of a constant state of readiness for change [49]. On the other hand, the structure in the seminar series, which alternates seminars for initiative, understanding and action conversations [66], is coherent with the need for iteration in systemic approaches [40,51,99]. In addition to this, the case shows that using this traditional academic space of conversations for a change-oriented process reduces resistance to change. In a sense, seminars become Trojan horses in academic contexts. However, for this to happen, the case reframes the concept of "seminar" following a relational approach instead of the usual logistical perspective [111].

In addition to this, the case seems to suggest that creating dialogical spaces at the group level impacts at the individual and institutional levels. Figure 5 synthesises the most relevant impacts, introducing a holistic point of view. Providing space for actual participation and listening contributes to shaping a shared and developmental change message, ensuring the five message domains: discrepancy, appropriateness, efficacy, principal support and personal valence [115]. In fact, the SDGs Seminars firstly allowed a multilevel diagnosis of the current readiness for change state $[37,71]$ to be undertaken, considering dimensions concerning the change content, the change-oriented process and the organizational context [103], as well as other aspects related to the characteristics of the individuals that belong to the organization, including cognitive, affective and behavioural components [37,62]. 


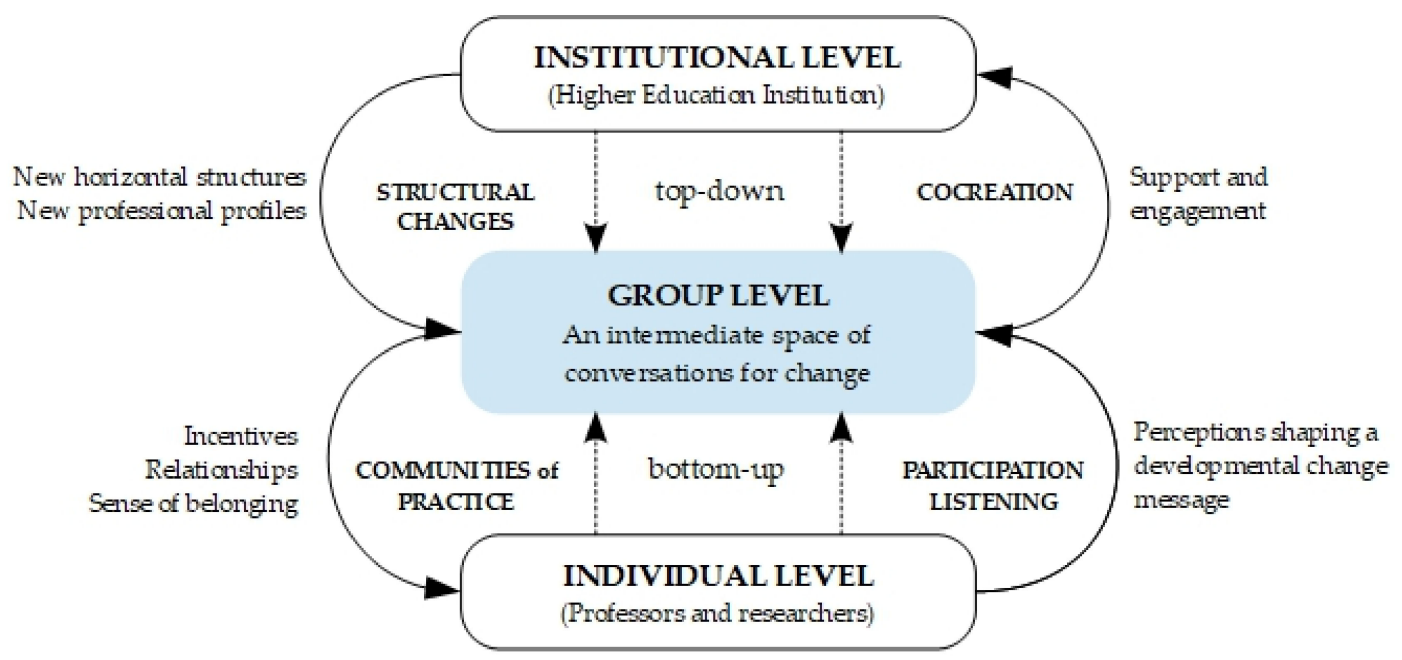

Figure 5. Impacts of a group level dialogical space of conversations for change on institutional and individual levels. Source: the authors.

The diagnosis served as a starting point to engage the faculty and research community in a cocreation process to develop an institutional strategy for sustainability. In a sense, dialogical spaces become a device for a cocreation culture to be experienced. For this purpose, two narratives are considered particularly key: First, the SDGs furnish an adequate framework to enhance collaborative culture and sustainability commitment in HEIs; nevertheless, due to their high abstraction level, a realization effort should be undertaken to bring them closer to the professors and researchers' daily work. Second, the "mission-oriented approach" [105] is thought to be extremely useful to activate collective action and the alignment of the individual incentives to the institutional policies.

Furthermore, the consolidation of the dialogical space also brought about the institutionalization of a collaborative working culture by means of (1) the creation of new horizontal structures which operate in a collaborative way (i.e., interdisciplinary communities of practice, strategic committees involving different disciplines and diverse academic positions and groups, etc.) and (2) the establishment of new professional profiles based on facilitation competences. These structural changes, especially the consolidation of research and learning communities of practice, generate new incentives for professors and researchers (i.e., exchange of good research, teaching and learning practices and materials, a better chance to participate in large-scale projects, connection of their research and teaching with real problems, etc.), whose sense of belonging is strengthened.

As stated above, the programme has been running while this article is being written and will continue into the next school year. The facilitation team is opening new crosscutting topics to engage those professors and researchers that have not already participated, and enabling the adoption of dialogical and developmental approaches in the recently created interdisciplinary structures. In addition to this, efforts are placed today in aligning the internal process to medium and long-term European policies, especially to those related to research (Horizon Europe, 2021-2027) and climate-neutrality (European Mission for 100 Climate-Neutral Cities by 2030). In particular, the UPM is working close to Madrid City Council, EIT Climate-KIC and other stakeholders through the platform Madrid Deep Demonstration, in order to help this city become one of the first European climate-neutral cities. These policies set a new direction to sustain the process at least during the next decade, translating the readiness for change of UPM's faculty and research community into concrete transformational actions.

A clear limitation of this research is that its conclusions are derived from a single case study. Although the SDGs Seminars at the UPM provide complex and detailed information about how to start moving to action in HEI transformation towards sustainability, it is difficult to generalize about such change processes. In addition to this, the authors were directly involved in the development of the initiative. This fact brings them a deep 
knowledge but also limits their impartiality. Further studies in different contexts and beyond HEIs would enable contrasting the applicability of the results. In addition to this, previous research suggests that female participation and leadership may influence creativity, inclusiveness and more balanced relationships [124]. Thus, in the light of the results, it would also be relevant to investigate the role of female leadership when creating teaching and research interdisciplinary structures. Finally, this study focused on physical spaces of conversations for change. However, the COVID-19 pandemic forced a spread of virtual formats, which were also experienced by the programme beginning in March 2020. Further research should also concentrate on understanding the special features and outcomes of digital spaces of conversations for change.

Author Contributions: Conceptualization, I.E.-L. and M.S.; methodology, I.E.-L., T.S.-C. and J.M.-S.; validation, A.G.-P., C.M. and T.S.-C.; formal analysis, I.E.-L.; investigation, I.E.-L.; resources, A.G.-P.; data curation, I.E.-L.; writing—original draft preparation, I.E.-L.; writing—review and editing, I.E.-L., M.S., T.S.-C. and J.M.-S.; visualization, I.E.-L.; supervision, C.M. and A.G.-P.; project administration, I.E.-L., M.S. and J.M.-S.; funding acquisition, C.M., I.E.-L. and J.M.-S. All authors have read and agreed to the published version of the manuscript.

Funding: The project corresponding to this case study and this doctoral research has been supported by funding from the Universidad Politécnica de Madrid (UPM).

Institutional Review Board Statement: Not applicable.

Informed Consent Statement: Informed consent was obtained from all subjects involved in the study.

Acknowledgments: The authors would like to acknowledge the hard work of the SDGs Seminars team, especially Julia Urquijo for the design of the developmental evaluation plan, Pablo Sastrón for his support to the facilitation team from October 2018 to July 2019 and Caren Camiscia for her strategic contribution to the design since November 2019. Moreover, we would like to acknowledge the indispensable contribution of all UPM staff involved in the process, especially Rocío Oña from the Unidad de Cultura Científica, the Gabinete de Tele-Educación for their support in the streaming and video recording of the sessions, the UPM and Schools' communication offices and the technical staff of the conference rooms.

Conflicts of Interest: The authors declare no conflict of interest.

\section{Appendix A}

This appendix contains additional information on the main sources of evidence employed for the action case study analysis. Further information on any of these documents may be requested from the authors of this article.

Table A1. Key documents associated with the initiative.

\begin{tabular}{|c|c|c|c|}
\hline Evidence & Date & Description & Available at \\
\hline Call for Proposals & April 2018 & $\begin{array}{l}\text { Call for Proposals from the } \\
\text { Vice-Rector's Office for } \\
\text { Research and Innovation } \\
\text { aimed at fostering } \\
\text { collaboration between R\&I } \\
\text { structures through the } \\
\text { design and deployment of } \\
\text { a programme of seminars }\end{array}$ & $\begin{array}{c}\text { https:/ / short.upm.es } \\
\text { /4xfok }\end{array}$ \\
\hline Proposal & May 2018 & $\begin{array}{l}\text { Submitted proposal to the } \\
\text { call for internal funding }\end{array}$ & $\begin{array}{c}\text { https://drive.upm.es } \\
\text { /index.php/s/5KkJA } \\
\text { EihFp6QRMh }\end{array}$ \\
\hline $\begin{array}{l}\text { Communication } \\
\text { Plan }\end{array}$ & October 2018 & $\begin{array}{l}\text { Includes the main } \\
\text { strategies and stakeholders } \\
\text { for the deployment of the } \\
\text { communication plan }\end{array}$ & $\begin{array}{l}\text { https://drive.upm.es } \\
\text { /index.php/s/KO1 } \\
\text { hHbfAN0lDbu1 }\end{array}$ \\
\hline
\end{tabular}


Table A1. Cont.

\begin{tabular}{|c|c|c|c|}
\hline Evidence & Date & Description & Available at \\
\hline $\begin{array}{l}\text { Monitoring and } \\
\text { Evaluation Plan }\end{array}$ & October 2018 & $\begin{array}{l}\text { Includes the main } \\
\text { strategies to assess the } \\
\text { process following a } \\
\text { developmental } \\
\text { evaluation approach }\end{array}$ & $\begin{array}{l}\text { https:/ / drive.upm.es } \\
\text { /index.php/s / KrqtW } \\
\text { f4hedCXO7U }\end{array}$ \\
\hline Homepage & since 2018 & $\begin{array}{l}\text { Homepage including the } \\
\text { rationale, information on } \\
\text { the coming events and } \\
\text { results from previous } \\
\text { sessions, relevant } \\
\text { literature, etc. }\end{array}$ & $\begin{array}{l}\text { http://www.upm.es } \\
\text { /Investigacion/difus } \\
\text { ion/SeminariosUPM }\end{array}$ \\
\hline Playlist & since 2018 & $\begin{array}{l}\text { Includes all the recorded } \\
\text { material related to } \\
\text { the sessions }\end{array}$ & $\begin{array}{l}\text { https://youtube.co } \\
\text { m/playlist?list=PLaz } \\
\text { AYOVsmcxBKcxGB } \\
\text { ZjNnQ_aqqJCfEkIs }\end{array}$ \\
\hline $\begin{array}{c}\text { Summary Video } \\
\text { 2018-2019 }\end{array}$ & July 2019 & $\begin{array}{l}\text { Summary of the sessions } \\
\text { organized between October } \\
2018 \text { and July } 2019\end{array}$ & $\begin{array}{c}\text { https://youtu.be/K } \\
\text { XG6nXoWj9E }\end{array}$ \\
\hline $\begin{array}{l}\text { Flickr album of the } \\
\text { opening session }\end{array}$ & October 2018 & - & $\begin{array}{c}\text { https://short.upm.es } \\
\text { /9cl3z }\end{array}$ \\
\hline
\end{tabular}

Table A2. Written and recorded material from the different activities organized.

\begin{tabular}{|c|c|c|c|}
\hline Session & Evidence & Date & Available at \\
\hline R\&I and the 2030 Agenda & $\begin{array}{l}\text { Video } \\
\text { Post }\end{array}$ & 23 October 2018 & $\begin{array}{c}\text { https://short.upm.es } \\
\text { /1k7q8 }\end{array}$ \\
\hline Introducing the SDGs: Workshop 1 & $\begin{array}{l}\text { Video } \\
\text { Post }\end{array}$ & 6 November 2018 & $\begin{array}{c}\text { https: } \\
\text { //short.upm.es/15te8 }\end{array}$ \\
\hline Introducing the SDGs: Workshop 2 & $\begin{array}{l}\text { Video } \\
\text { Post }\end{array}$ & 20 November 2018 & $\begin{array}{c}\text { https: } \\
\text { //short.upm.es/15te8 }\end{array}$ \\
\hline $\begin{array}{l}\text { Implications of the } 2030 \text { Agenda } \\
\text { for Research Funding }\end{array}$ & $\begin{array}{l}\text { Video } \\
\text { Post }\end{array}$ & 11 December 2018 & $\begin{array}{c}\text { https://short.upm.es } \\
\text { / kuppg }\end{array}$ \\
\hline $\begin{array}{l}\text { How to Increase UPM's Impact on } \\
\text { Energy Transition? }\end{array}$ & $\begin{array}{l}\text { Video } \\
\text { Post }\end{array}$ & 5 March 2019 & $\begin{array}{l}\text { https://short.upm.es } \\
\text { /7edum }\end{array}$ \\
\hline $\begin{array}{c}\text { Research as a Key to Accelerate } \\
\text { Energy Transition }\end{array}$ & $\begin{array}{l}\text { Video } \\
\text { Post }\end{array}$ & 19 March 2019 & $\begin{array}{c}\text { https://short.upm.es } \\
\text { /ss218 }\end{array}$ \\
\hline Towards a UPM Mission for 2030 & Post & 2 April 2019 & $\begin{array}{c}\text { https://short.upm.es } \\
\text { /9xygw }\end{array}$ \\
\hline $\begin{array}{l}\text { UPM's Contribution to Circular } \\
\text { Economy and New Materials }\end{array}$ & $\begin{array}{l}\text { Video } \\
\text { Post }\end{array}$ & 21 May 2019 & $\begin{array}{l}\text { https: } \\
\text { //short.upm.es/i24ls }\end{array}$ \\
\hline $\begin{array}{l}\text { Saving the Seas: Research for a } \\
\text { Sustainable Production and } \\
\text { Consumption Model }\end{array}$ & $\begin{array}{l}\text { Video } \\
\text { Post }\end{array}$ & 4 June 2019 & $\begin{array}{c}\text { https:/ / short.upm.es } \\
\text { /e85uy }\end{array}$ \\
\hline Towards a Circular UPM in 2030 & Post & 18 June 2019 & $\begin{array}{c}\text { https://short.upm.es } \\
\text { /wrms4 }\end{array}$ \\
\hline 2018-2019 Closure Session & $\begin{array}{l}\text { Video } \\
\text { Post }\end{array}$ & 9 July 2019 & $\begin{array}{l}\text { https://short.upm.es } \\
\text { / mifgp }\end{array}$ \\
\hline $\begin{array}{l}\text { 2019-2020 Opening Session: } \\
\text { UPM's Commitment to SDGs }\end{array}$ & $\begin{array}{l}\text { Video } \\
\text { Post }\end{array}$ & 4 October 2019 & $\begin{array}{c}\text { https: } \\
\text { //short.upm.es/ejsjy }\end{array}$ \\
\hline
\end{tabular}


Table A2. Cont.

\begin{tabular}{|c|c|c|c|}
\hline Session & Evidence & Date & Available at \\
\hline $\begin{array}{c}\text { How to Reduce the Land Impact } \\
\text { of Diet? }\end{array}$ & $\begin{array}{l}\text { Video } \\
\text { Post }\end{array}$ & 16 November 2019 & $\begin{array}{c}\text { https: / / short.upm.es } \\
\text { / 6eey5 }\end{array}$ \\
\hline $\begin{array}{l}\text { Vegetal Biodiversity: A Tool } \\
\text { against Climate Change }\end{array}$ & $\begin{array}{l}\text { Video } \\
\text { Post }\end{array}$ & 21 January 2020 & $\begin{array}{c}\text { https://short.upm.es } \\
\text { /vi3bp }\end{array}$ \\
\hline $\begin{array}{c}\text { Extreme Climate Events } \\
\text { Prevention and Management }\end{array}$ & $\begin{array}{l}\text { Video } \\
\text { Post }\end{array}$ & 4 February 2020 & $\begin{array}{c}\text { https: / / short.upm.es } \\
\text { /a3pzr }\end{array}$ \\
\hline $\begin{array}{l}\text { Decarbonizing UPM through } \\
\text { nature and food systems }\end{array}$ & $\begin{array}{l}\text { Video } \\
\text { Post }\end{array}$ & 18 February 2020 & $\begin{array}{c}\text { https://short.upm.es } \\
\text { /uowgc }\end{array}$ \\
\hline
\end{tabular}

Table A3. Results of the surveys aiming to assess professors and researchers' perception on SDGs.

\begin{tabular}{ccc}
\hline Evidence & Date & Available at \\
\hline Survey results 00 & 23 October 2018 & https://short.upm.es/d2afr \\
\hline Survey report 00 & 23 October 2018 & https://short.upm.es/2ercp \\
\hline Survey results 01 & 6 November 2018 & https://short.upm.es/hstjr \\
\hline Survey report 01 & 6 November 2018 & https://short.upm.es/rfahr \\
\hline Survey results 02 & 11 November 2018 & https://short.upm.es/8yv2y \\
\hline Survey report 02 & 11 November 2018 & https://short.upm.es/th9v6 \\
\hline Survey results 03 & 11 December 2018 & https://short.upm.es/f73cp \\
\hline Survey report 03 & 11 December 2018 & https://short.upm.es/aejue \\
\hline
\end{tabular}

Table A4. Meta-evaluation material.

\begin{tabular}{cccc}
\hline Evidence & Date & Description & Available at \\
\hline Report 2018 & January 2019 & $\begin{array}{c}\text { Includes a summary of the main } \\
\text { activities and results: 4 sessions, } \\
\text { 273 participants, 4 surveys. }\end{array}$ & $\begin{array}{c}\text { https://drive.upm.es } \\
\text { index.php/s/PqQ } \\
\text { 4RI5qnJHnFb }\end{array}$ \\
\hline \multirow{2}{*}{ Report 2019 } & January 2020 & $\begin{array}{c}\text { Includes a summary of the main } \\
\text { activities and results: } 9 \text { sessions, } \\
\text { 610 participants. }\end{array}$ & $\begin{array}{c}\text { https://drive.upm.es } \\
\text { /index.php/s/Jj81I } \\
\text { wdjpFZNiRp }\end{array}$ \\
\hline \multirow{2}{*}{ Report 2020 } & January 2021 & $\begin{array}{c}\text { Includes a summary of the main } \\
\text { activities and results: 3 sessions, } \\
\text { 198 participants until } \\
\text { March 2020. }\end{array}$ & $\begin{array}{c}\text { https://drive.upm.es } \\
\text { /index.php/s/WLIyl } \\
\text { eisHihcfqR }\end{array}$ \\
\hline
\end{tabular}

\section{Appendix B}

This appendix contains additional information on the sessions organized, including aspects such as the type of conversation deployed, the number of participants and photographs showcasing the evolution of the spaces for conversations. 
Table A5. Further information on SDGs Seminars sessions.

\begin{tabular}{|c|c|c|c|c|c|}
\hline Series & Title & Date & Type & Panellists & Participants \\
\hline \multirow{4}{*}{$\begin{array}{l}\text { Introducing } \\
\text { SDGs }\end{array}$} & $\begin{array}{l}\text { R\&I and the } \\
2030 \text { Agenda }\end{array}$ & 23 October 2018 & Initiative & $\begin{array}{c}\text { Rector } \\
4 \text { Vice-Rectors } \\
\text { Main responsibility of } \\
2030 \text { Agenda in the } \\
\text { Spanish government }\end{array}$ & 114 \\
\hline & $\begin{array}{l}\text { Introducing SDGs: } \\
\text { Workshop } 1\end{array}$ & 6 November 2018 & Understanding & $\begin{array}{l}\text { School Director } \\
4 \text { prestigious } \\
\text { Professors }\end{array}$ & 70 \\
\hline & $\begin{array}{l}\text { Introducing SDGs: } \\
\text { Workshop } 2\end{array}$ & 20 November 2018 & Understanding & $\begin{array}{c}2 \text { School Directors } \\
4 \text { prestigious } \\
\text { Professors }\end{array}$ & 42 \\
\hline & $\begin{array}{l}\text { Implications of } \\
2030 \text { Agenda for } \\
\text { Research Funding }\end{array}$ & 11 December 2018 & $\begin{array}{l}\text { Understanding 2: } \\
\text { Inspirational }\end{array}$ & $\begin{array}{c}\text { School Director } \\
3 \text { Prestigious figures } \\
\text { from academic, } \\
\text { public and } \\
\text { private sector }\end{array}$ & 47 \\
\hline \multirow{3}{*}{$\begin{array}{c}\text { Energy } \\
\text { Transition } \\
\text { and Climate } \\
\text { Change }\end{array}$} & $\begin{array}{l}\text { How to Increase } \\
\text { UPM's Impact on } \\
\text { Energy Transition? }\end{array}$ & 5 March 2019 & $\begin{array}{l}\text { Understanding 1: } \\
\text { Connections }\end{array}$ & $\begin{array}{l}\text { Vice-Rector } \\
\text { UPM researchers } \\
\text { and } \mathrm{PhD}\end{array}$ & 72 \\
\hline & $\begin{array}{l}\text { Research as a Key } \\
\text { to Accelerate } \\
\text { Energy Transition }\end{array}$ & 19 March 2019 & $\begin{array}{l}\text { Understanding 2: } \\
\text { Inspirational }\end{array}$ & $\begin{array}{c}\text { Rector } \\
\text { Ecology Transition } \\
\text { Minister and } \\
3 \text { prestigious figures } \\
\text { from academia, } \\
\text { public and } \\
\text { private sectors }\end{array}$ & 202 \\
\hline & $\begin{array}{l}\text { Towards a UPM } \\
\text { Mission for } 2030\end{array}$ & 2 April 2019 & $\begin{array}{l}\text { Cocreation } \\
\text { Workshop }\end{array}$ & $\begin{array}{c}\text { Vice-Rector of } \\
\text { Quality } \\
\text { Researchers }\end{array}$ & 25 \\
\hline \multirow{3}{*}{$\begin{array}{l}\text { Circular } \\
\text { Economy } \\
\text { and New } \\
\text { Materials }\end{array}$} & $\begin{array}{c}\text { UPM's } \\
\text { Contribution to } \\
\text { Circular Economy } \\
\text { and New Materials }\end{array}$ & 21 May 2019 & $\begin{array}{l}\text { Understanding 1: } \\
\text { Connections }\end{array}$ & $\begin{array}{l}\text { Vice-Rector } \\
\text { UPM researchers } \\
\text { and } \mathrm{PhD}\end{array}$ & 34 \\
\hline & $\begin{array}{l}\text { Saving Sees: } \\
\text { Research for a } \\
\text { Sustainable } \\
\text { Production and } \\
\text { Consump- } \\
\text { tion Model }\end{array}$ & 4 June 2019 & $\begin{array}{l}\text { Understanding 2: } \\
\text { Inspirational }\end{array}$ & $\begin{array}{c}\text { Vice-Rectors } \\
3 \text { prestigious figures } \\
\text { from academic, } \\
\text { public and } \\
\text { private sectors }\end{array}$ & 65 \\
\hline & $\begin{array}{c}\text { Towards a Circular } \\
\text { UPM in } 2030\end{array}$ & 18 June 2019 & $\begin{array}{l}\text { Cocreation } \\
\text { Workshop }\end{array}$ & Researchers & 25 \\
\hline- & $\begin{array}{c}2018-2019 \\
\text { Closure Session }\end{array}$ & 9 July 2019 & Closure & $\begin{array}{l}\text { Vice-Rector for } \\
\text { Research and } \\
\text { Vice-Rector } \\
\text { for Quality }\end{array}$ & 35 \\
\hline- & $\begin{array}{l}\text { 2019-2020 Opening } \\
\text { Session: UPM's } \\
\text { Commitment } \\
\text { to SDGs }\end{array}$ & 4 October 2019 & Initiative & $\begin{array}{c}\text { Rector } \\
\text { Vice-Rectors } \\
\text { School Directors and } \\
\text { Faculty Deans }\end{array}$ & 102 \\
\hline \multirow{4}{*}{$\begin{array}{l}\text { Sustainable } \\
\text { Natural } \\
\text { Resource } \\
\text { Manage- } \\
\text { ment }\end{array}$} & $\begin{array}{l}\text { How to Reduce } \\
\text { Land Impact } \\
\text { of Diet? }\end{array}$ & 16 November 2019 & $\begin{array}{l}\text { Understanding 1: } \\
\text { Connections }\end{array}$ & $\begin{array}{c}\text { Vice-Rector } \\
\text { School Director } \\
\text { UPM researchers } \\
\text { and PhD }\end{array}$ & 50 \\
\hline & $\begin{array}{c}\text { Vegetal } \\
\text { Biodiversity: A } \\
\text { Tool against } \\
\text { Climate Change }\end{array}$ & 21 January 2020 & $\begin{array}{l}\text { Understanding 2: } \\
\text { Inspirational }\end{array}$ & $\begin{array}{c}\text { School Director } \\
4 \text { prestigious figures } \\
\text { from academic, } \\
\text { public and } \\
\text { civil sectors }\end{array}$ & 89 \\
\hline & $\begin{array}{l}\text { Extreme Climate } \\
\text { Events Prevention } \\
\text { and Management }\end{array}$ & 4 February 2020 & $\begin{array}{l}\text { Understanding 2: } \\
\text { Inspirational }\end{array}$ & $\begin{array}{c}\text { Vice-Rector } \\
\text { School Director } \\
5 \text { prestigious figures } \\
\text { from academic and } \\
\text { public sector }\end{array}$ & 61 \\
\hline & $\begin{array}{l}\text { Decarbonizing } \\
\text { UPM through } \\
\text { nature and } \\
\text { food systems }\end{array}$ & 18 February 2020 & $\begin{array}{l}\text { Cocreation } \\
\text { Workshop }\end{array}$ & $\begin{array}{c}\text { Director of Research } \\
\text { Centre } \\
\text { Researchers }\end{array}$ & 48 \\
\hline
\end{tabular}




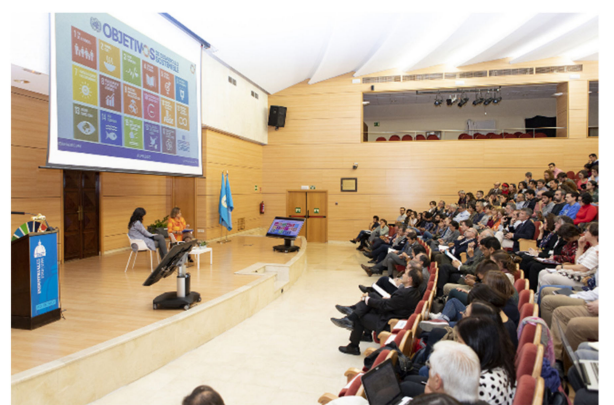

(a)

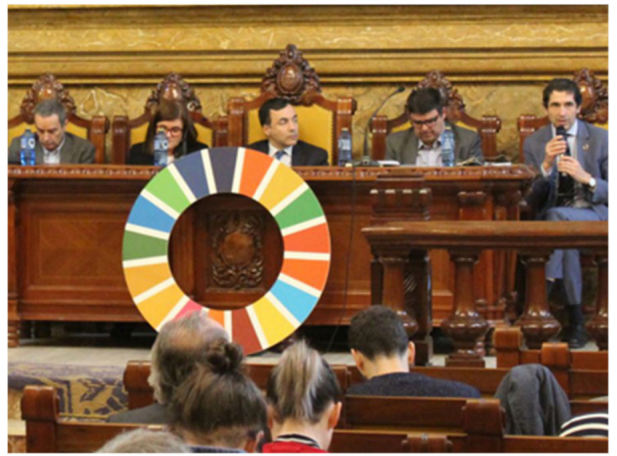

(c)

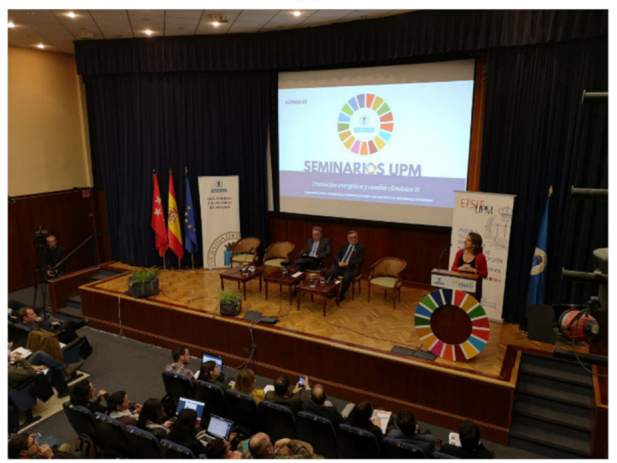

(e)

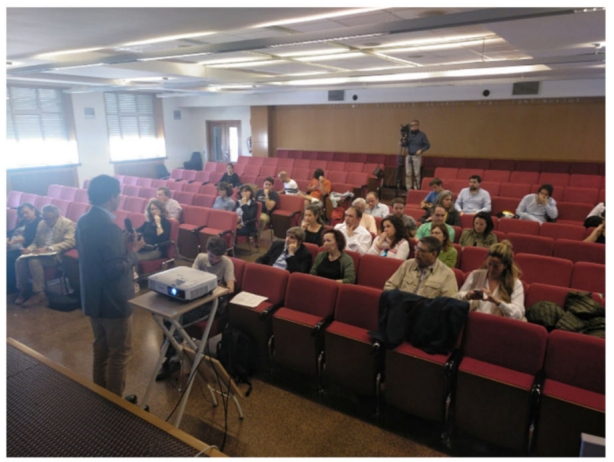

(g)

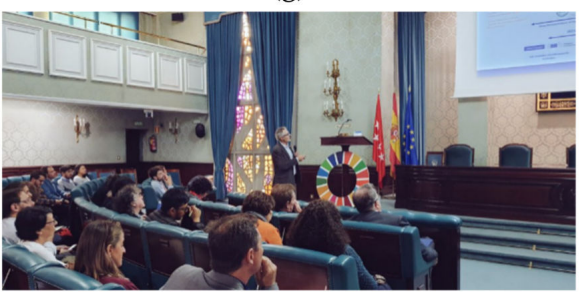

(i)

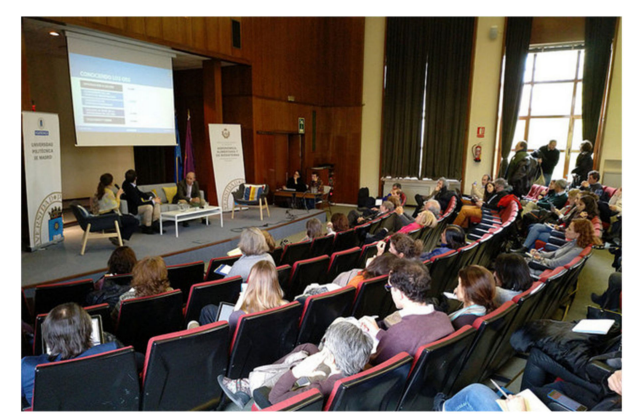

(b)

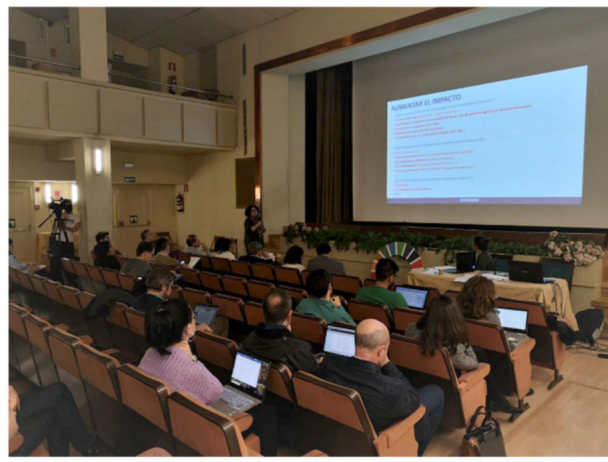

(d)

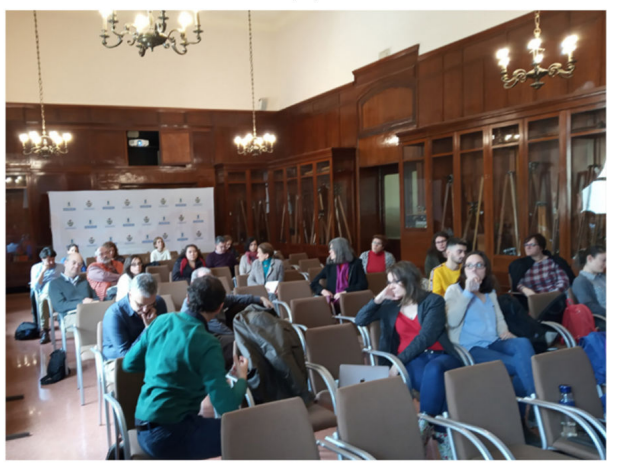

(f)

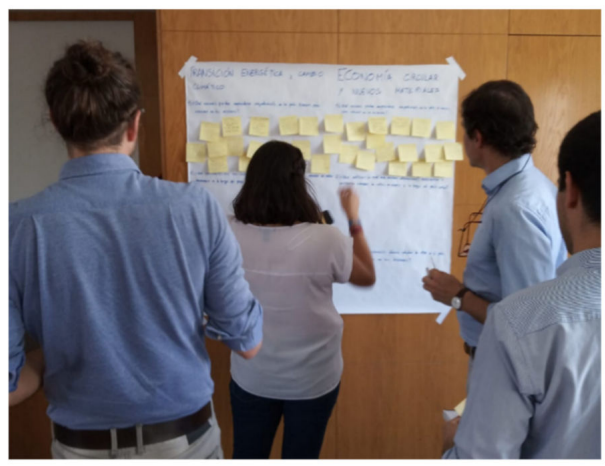

(h)

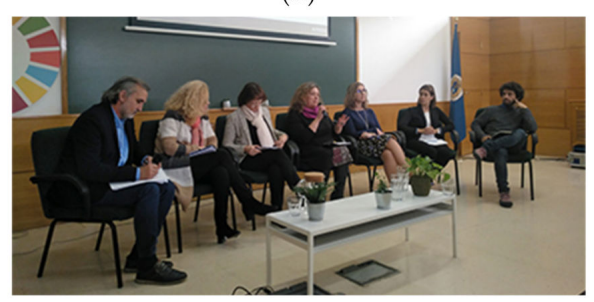

(j)

Figure A1. Cont. 


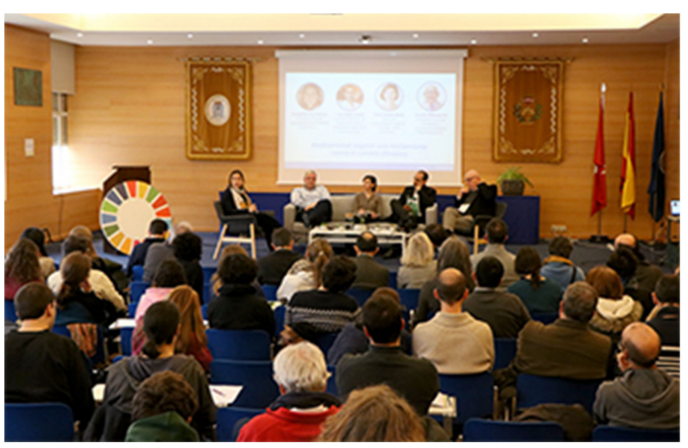

(k)

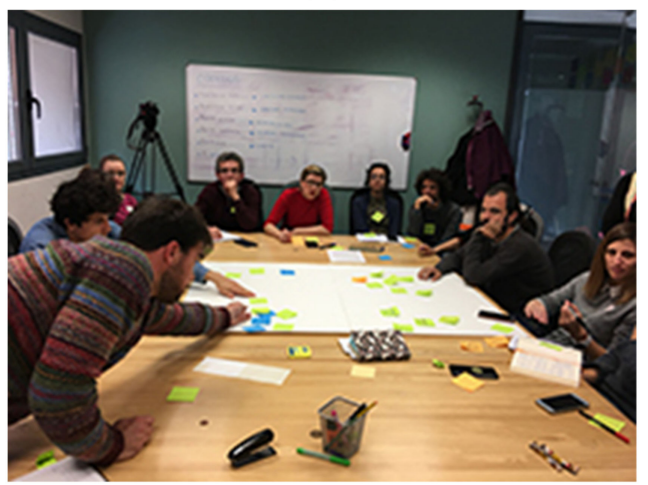

(m)

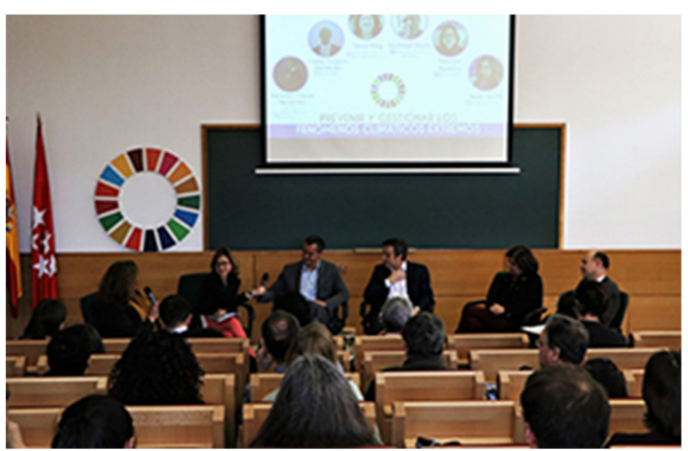

(1)

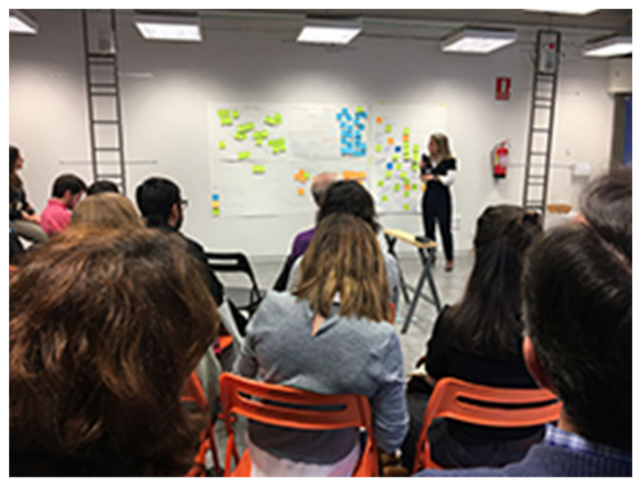

(n)

Figure A1. Photographs showcasing the evolution of selected locations: (a) Seminar 1: "R\&I and the 2030 Agenda" (initiative conversation); (b) Seminar 2: "Introducing SDGs" (understanding conversation); (c) Seminar 4: "Implications of the 2030 Agenda for Research Funding"(understanding-inspirational); (d) Seminar 5: "How to Increase UPM's Impact on Energy Transition?"(understanding-connection); (e) Seminar 6: "Research as a Key to Accelerate Energy Transition"(understandinginspirational); (f) Seminar 7: “Towards a UPM Mission for 2030"(conversation for action); (g) Seminar 8: “UPM's Contribution to Circular Economy and New Materials" (understanding-connection); (h) Seminar 10: “Towards a Circular UPM in 2030" (action); (i) Seminar 11: “2018-2019 Closure Session” (closure conversation); (j) Seminar 12: “2019-2020 Opening Session: UPM's Commitment to SDGs" (initiative conversation); (k) Seminar 13: "How to Reduce Land Impact of Diet?" (understanding-connection); (l) Seminar 14: "Vegetal Biodiversity: A Tool against Climate Change" (understandinginspirational); (m) Seminar 15: “Decarbonizing UPM through nature and food systems", workshop space (action); (n) Seminar 16: "Decarbonizing UPM through nature and food systems", collective interpretation space (action). Source: Universidad Politécnica de Madrid.

\section{Appendix C} Seminars.

This appendix includes the surveys used during the first three sessions of the SDGs

Table A6. Survey "Introducing SDGs".

\begin{tabular}{|c|c|}
\hline Questions & Answers \\
\hline (0) Demographic data & $\begin{array}{l}\text { such as gender, age, academic position, } \\
\text { research group and centre, department, } \\
\text { school, etc. }\end{array}$ \\
\hline \multirow{4}{*}{$\begin{array}{l}\text { (1) How would you qualify your knowledge of the } \\
\text { SDGs before the session? }\end{array}$} & I did not know the SDGs. \\
\hline & I had heard something about the SDGs. \\
\hline & I had enough information. \\
\hline & I had lots of information. \\
\hline (2) My research group contributes the most to ... & SDG $1 \ldots$ SDG 17 \\
\hline (3) My research group contributes secondarily to ... & SDG $1 \ldots$ SDG 17 \\
\hline
\end{tabular}


Table A6. Cont.

\begin{tabular}{cc}
\hline Questions & Answers \\
\hline (4) Achieving SDGs by 2030 is & highly likely. \\
\cline { 2 - 2 } & quite likely. \\
\cline { 2 - 2 } & quite unlikely. \\
\cline { 2 - 2 } (5) Related to my research line, I consider that the & unlikely. \\
\cline { 2 - 2 } & very relevant. \\
\cline { 2 - 2 } (6) In your opinion, can SDGs represent an & quite relevant. \\
opportunity to address the challenges faced by the & little relevant. \\
UPM? Why? & irrelevant. \\
\hline
\end{tabular}

Table A7. "Thermometer of Interdisciplinarity".

\begin{tabular}{|c|c|}
\hline Scale & Question \\
\hline Demographic data & $\begin{array}{c}\text { such as gender, age, academic position, research group and } \\
\text { centre, department, school ... }\end{array}$ \\
\hline \multirow[b]{2}{*}{ Individual } & $\begin{array}{l}\text { I usually work with colleagues from very different areas. } \\
\text { Gradient } 1 \text { (not agree)-4 (very agree) }\end{array}$ \\
\hline & $\begin{array}{l}\text { I have published papers which include theoretical } \\
\text { frameworks from different disciplines and/or in } \\
\text { collaboration with researchers from different disciplines. } \\
\text { Gradient } 1 \text { (not agree)-4 (very agree) }\end{array}$ \\
\hline \multirow{6}{*}{ Research group } & $\begin{array}{l}\text { In my research group, we usually work with non-academic } \\
\text { experts, with whom we maintain stable collaborative } \\
\text { relationships. Gradient } 1 \text { (not agree)-4 (very agree). }\end{array}$ \\
\hline & $\begin{array}{c}\text { In my research group, relationships are not very hierarchical. } \\
\text { I consider it a safe environment for discussion. } \\
\text { Gradient } 1 \text { (not agree)-4 (very agree). }\end{array}$ \\
\hline & $\begin{array}{l}\text { We usually contrast our ideas and progress with } \\
\text { non-academic stakeholders (users, other social sectors, etc.). } \\
\text { Gradient } 1 \text { (not agree)-4 (very agree). }\end{array}$ \\
\hline & $\begin{array}{l}\text { In my group, the publication of policy papers and the } \\
\text { appearance in the media are positively valued, despite their } \\
\text { low curricular profitability. } \\
\text { Gradient } 1 \text { (not agree)-4 (very agree). }\end{array}$ \\
\hline & $\begin{array}{c}\text { My group is diverse in terms of academic education, gender, } \\
\text { age, ethnic group, nationality ... } \\
\text { Gradient } 1 \text { (not agree)-4 (very agree). }\end{array}$ \\
\hline & $\begin{array}{l}\text { In my research group, we share a model to assess the } \\
\text { socio-economic impact of our investigation. } \\
\text { Gradient } 1 \text { (not agree)-4 (very agree). }\end{array}$ \\
\hline University & $\begin{array}{l}\text { In my opinion, the structure and processes in my university } \\
\text { encourage interdisciplinarity. } \\
\text { Gradient } 1 \text { (not agree)-4 (very agree). } \\
\text { In my knowledge field, the training of young researchers } \\
\text { with an interdisciplinary vocation is encouraged. } \\
\text { Gradient } 1 \text { (not agree)-4 (very agree). }\end{array}$ \\
\hline
\end{tabular}




\section{References}

1. United Nations. Transforming Our World: The 2030 Agenda for Sustainable Development. Resolution 70/1 Adopted by the United Nations General Assembly on 25 September 2015. Available online: https://sdgs.un.org/2030agenda (accessed on 3 February 2021).

2. Soini, K.; Jurgilevich, A.; Pietikäinen, J.; Korhonen-Kurki, K. Universities Responding to the Call for Sustainability: A Typology of Sustainability Centres. J. Clean. Prod. 2018, 170, 1423-1432. [CrossRef]

3. Cortese, A.D. The Critical Role of Higher Education in Creating a Sustainable Future. Plan. High. Educ. 2003, 31, 15-22.

4. Hoover, E.; Harder, M.K. What Lies beneath the Surface? The Hidden Complexities of Organizational Change for Sustainability in Higher Education. J. Clean. Prod. 2015, 106, 175-188. [CrossRef]

5. Soini, K.; Dessein, J. Culture-Sustainability Relation: Towards a Conceptual Framework. Sustainability 2016, 8, 167. [CrossRef]

6. Fullan, M. The Elusive Nature of Whole System Improvement in Education. J. Educ. Chang. 2016, 17, 539-544. [CrossRef]

7. Becher, T. Tribus y Territorios Académicos: La Indagación Intelectual y la Cultura de las Disciplinas, 1st ed.; Gedisa: Barcelona, Spain, 2001; ISBN 978-84-7432-757-1.

8. Clark, B.R.; Kent, R.; Universidad Autónoma Metropolitana; México, M.; Unidad Azcapotzalco. El Sistema de Educación Superior: Una Visión Comparativa de la Organización Académica; UAM-Azcapotzalco, Nueva Imagen: Mexico City, México, 1992; ISBN 978-968-39-0396-9.

9. Maponya, P. Fostering the Culture of Knowledge Sharing in Higher Education. S. Afr. J. High. Educ. 2006, 19, 900-911. [CrossRef]

10. Kezar, A. Moving from I to, Reorganizing for Collaboration in Higher Education. Chang. Mag. High. Learn. 2005, 37, 50-57. [CrossRef]

11. Lozano, R.; Lukman, R.; Lozano, F.J.; Huisingh, D.; Lambrechts, W. Declarations for Sustainability in Higher Education: Becoming Better Leaders, through Addressing the University System. J. Clean. Prod. 2013, 48, 10-19. [CrossRef]

12. Findler, F.; Schönherr, N.; Lozano, R.; Reider, D.; Martinuzzi, A. The Impacts of Higher Education Institutions on Sustainable Development: A Review and Conceptualization. Int. J. Sustain. High. Educ. 2019, 20, 22. [CrossRef]

13. Biswas, A.K.; Kirchherr, J. No One Is Reading You. Available online: https://www.straitstimes.com/opinion/prof-no-one-is-re ading-you (accessed on 19 July 2021).

14. Stephens, J.C.; Graham, A.C. Toward an Empirical Research Agenda for Sustainability in Higher Education: Exploring the Transition Management Framework. J. Clean. Prod. 2010, 18, 611-618. [CrossRef]

15. United Nations. The Road to Dignity by 2030: Ending Poverty, Transforming All Lives and Protecting the Planet. Synthesis Report of the Secretary-General. On the Post-2015 Agenda; United Nations: New York, NY, USA, 2014.

16. Dzimińska, M.; Fijałkowska, J.; Sułkowski, Ł. Trust-Based Quality Culture Conceptual Model for Higher Education Institutions. Sustainability 2018, 10, 2599. [CrossRef]

17. Purcell, W.M.; Henriksen, H.; Spengler, J.D. Universities as the Engine of Transformational Sustainability toward Delivering the Sustainable Development Goals: "Living Labs" for Sustainability. Int. J. Sustain. High. Educ. 2019, 20, 1343-1357. [CrossRef]

18. Stephens, J.C.; Hernandez, M.E.; Román, M.; Graham, A.C.; Scholz, R.W. Higher Education as a Change Agent for Sustainability in Different Cultures and Contexts. Int. J. Sustain. High. Educ. 2008, 9, 317-338. [CrossRef]

19. Hansen, J.A.; Lehmann, M. Agents of Change: Universities as Development Hubs. J. Clean. Prod. 2006, 14, 820-829. [CrossRef]

20. SDSN Australia/Pacific. Getting Started with the SDGs in Universities: A Guide for Universities, Higher Education Institutions, and the Academic Sector, Australia, New Zealand and Pacific ed.; Sustainable Development Solutions Network: Melbourne, VIC, Australia, 2017.

21. Lozano, R. Incorporation and Institutionalization of SD into Universities: Breaking through Barriers to Change. J. Clean. Prod. 2006, 14, 787-796. [CrossRef]

22. Lozano, R.; Ceulemans, K.; Alonso-Almeida, M.; Huisingh, D.; Lozano, F.J.; Waas, T.; Lambrechts, W.; Lukman, R.; Hugé, J. A Review of Commitment and Implementation of Sustainable Development in Higher Education: Results from a Worldwide Survey. J. Clean. Prod. 2015, 108, 1-18. [CrossRef]

23. Kang, L.; Xu, L. Creating Sustainable Universities: Organizational Pathways of Transformation. Eur. J. Sustain. Dev. 2018, 7, 339. [CrossRef]

24. Disterheft, A.; Caeiro, S.; Azeiteiro, U.M.; Leal Filho, W. Sustainability Science and Education for Sustainable Development in Universities: A Way for Transition. In Sustainability Assessment Tools in Higher Education Institutions; Caeiro, S., Filho, W.L., Jabbour, C., Azeiteiro, U.M., Eds.; Springer International Publishing: Cham, Switzerland, 2013; pp. 3-27, ISBN 978-3-319-02374-8.

25. Bautista-Puig, N.; Sanz-Casado, E. Sustainability Practices in Spanish Higher Education Institutions: An Overview of Status and Implementation. J. Clean. Prod. 2021, 295, 126320. [CrossRef]

26. Sanchez-Carrillo, J.C.; Cadarso, M.A.; Tobarra, M.A. Embracing Higher Education Leadership in Sustainability: A Systematic Review. J. Clean. Prod. 2021, 298, 126675. [CrossRef]

27. Leal Filho, W.; Wu, Y.-C.J.; Brandli, L.L.; Avila, L.V.; Azeiteiro, U.M.; Caeiro, S.; da Rosa Gama Madruga, L.R. Identifying and Overcoming Obstacles to the Implementation of Sustainable Development at Universities. J. Integr. Environ. Sci. 2017, 14, 93-108. [CrossRef]

28. Bögel, P.; Pereverza, K.; Upham, P.; Kordas, O. Linking Socio-Technical Transition Studies and Organisational Change Management: Steps towards an Integrative, Multi-Scale Heuristic. J. Clean. Prod. 2019, 232, 359-368. [CrossRef]

29. Peters, B.G. Managing Horizontal Government: The Politics of Co-Ordination. Public Adm. 1998, 76, 295-311. [CrossRef] 
30. Soberón, M.; Sánchez-Chaparro, T.; Urquijo, J.; Pereira, D. Introducing an Organizational Perspective in SDG Implementation in the Public Sector in Spain: The Case of the Former Ministry of Agriculture, Fisheries, Food and Environment. Sustainability 2020, 12, 9959. [CrossRef]

31. Roberts, N. Wicked Problems and Network Approaches to Resolution. Int. Public Manag. Rev. 2000, 1, 20.

32. Horan, D. A New Approach to Partnerships for SDG Transformations. Sustainability 2019, 11, 4947. [CrossRef]

33. Brinkhurst, M.; Rose, P.; Maurice, G.; Ackerman, J.D. Achieving Campus Sustainability: Top-down, Bottom-up, or Neither? Int. J Sustain. High. Educ. 2011, 12, 338-354. [CrossRef]

34. Armenakis, A.A.; Harris, S.G.; Mossholder, K.W. Creating Readiness for Organizational Change. Hum. Relat. 1993, 46, 681-703. [CrossRef]

35. Van de Ven, A.H.; Poole, M.S. Explaining Development and Change in Organizations. Acad. Manag. Rev. 1995, 20, 510. [CrossRef]

36. Armenakis, A.A.; Harris, S.G. Crafting a Change Message to Create Transformational Readiness. J. Organ. Chang. Manag. 2002, 15, 169-183. [CrossRef]

37. Rafferty, A.E.; Jimmieson, N.L.; Armenakis, A.A. Change Readiness: A Multilevel Review. J. Manag. 2013, 39, 110-135. [CrossRef]

38. Universidad Politécnica de Madrid. Website of the programme "Seminarios UPM: Tecnología e Innovación Para Los Objetivos de Desarrollo Sostenible". Available online: https://www.upm.es/Investigacion/difusion/SeminariosUPM (accessed on 27 July 2021).

39. Uhl, C. Process and Practice: Creating the Sustainable University. In Sustainability on Campus: Stories and Strategies for Change; MIT Press: Cambridge, MA, USA, 2004; pp. 29-47.

40. Wang, T.; Olivier, D.F.; Chen, P. Creating Individual and Organizational Readiness for Change: Conceptualization of System Readiness for Change in School Education. Int. J. Leadersh. Educ. 2020, 1-25. [CrossRef]

41. Moreno-Serna, J.; Sánchez-Chaparro, T.; Mazorra, J.; Arzamendi, A.; Stott, L.; Mataix, C. Transformational Collaboration for the SDGs: The Alianza Shire's Work to Provide Energy Access in Refugee Camps and Host Communities. Sustainability 2020, 12, 539. [CrossRef]

42. Ramísio, P.J.; Pinto, L.M.C.; Gouveia, N.; Costa, H.; Arezes, D. Sustainability Strategy in Higher Education Institutions: Lessons Learned from a Nine-Year Case Study. J. Clean. Prod. 2019, 222, 300-309. [CrossRef]

43. Barth, M.; Rieckmann, M. Academic Staff Development as a Catalyst for Curriculum Change towards Education for Sustainable Development: An Output Perspective. J. Clean. Prod. 2012, 26, 28-36. [CrossRef]

44. Dzimińska, M.; Fijałkowska, J.; Sułkowski, Ł. A Conceptual Model Proposal: Universities as Culture Change Agents for Sustainable Development. Sustainability 2020, 12, 4635. [CrossRef]

45. Sennett, R. Juntos: Rituales, Placeres y Política de Cooperación; Colección Argumentos; Anagrama: Barcelona, Spain, 2012; ISBN 978-84-339-6348-2.

46. Weber, E.P.; Khademian, A.M. Wicked Problems, Knowledge Challenges, and Collaborative Capacity Builders in Network Settings. Public Adm. Rev. 2008, 68, 334-349. [CrossRef]

47. Sharp, L. Green Campuses: The Road from Little Victories to Systemic Transformation. Int. J. Sustain. High. Educ. 2002, 3, 128-145. [CrossRef]

48. Purcell, W.M.; Chahine, T. Leadership and Governance Frameworks Driving Transformational Change in an Entrepreneurial UK University. Leadersh. Organ. Dev. J. 2019, 40, 612-623. [CrossRef]

49. Vakola, M. Multilevel Readiness to Organizational Change: A Conceptual Approach. J. Chang. Manag. 2013, 13, 96-109. [CrossRef]

50. Senge, P.M. The Fifth Discipline: The Art and Practice of the Learning Organization, Review and updated ed.; Random House Business Books: London, UK, 2006; ISBN 978-1-905211-20-3.

51. Marshak, R.J.; Grant, D. Organizational Discourse and New Organization Development Practices. Br. J. Manag. 2008, 19, S7-S19. [CrossRef]

52. Dozois, E.; Langlois, M.; Blanchet-Cohen, N.; J.W. McConnell Family Foundation; University of Victoria (B.C.); International Institute for Child Rights and Development. DE 201: A Practitioner's Guide to Developmental Evaluation; J.W. McConnell Family Foundation: Montréal, QC, Canada, 2011.

53. Patton, M.Q. Developmental Evaluation. Eval. Pract. 1994, 15, 311-319. [CrossRef]

54. Gamble, J.A.A. A Developmental Evaluation Primer, 1st ed.; The J.W. McConnell Family Foundation: Montréal, QC, Canada, 2008.

55. Patton, M.Q. Developmental Evaluation: Applying Complexity Concepts to Enhance Innovation and Use, 1st ed.; Guilford Press: New York, NY, USA, 2010.

56. Lewin, K. Field Theory in Social Science: Selected Theoretical Papers (Edited by Dorwin Cartwright); Harpers: Oxford, UK, 1951.

57. Wanberg, C.R.; Banas, J.T. Predictors and Outcomes of Openness to Changes in a Reorganizing Workplace. J. Appl. Psychol. 2000, 85, 132-142. [CrossRef]

58. Veiga Ávila, L.; Beuron, T.A.; Brandli, L.L.; Damke, L.I.; Pereira, R.S.; Klein, L.L. Barriers to Innovation and Sustainability in Universities: An International Comparison. Int. J. Sustain. High. Educ. 2019, 20, 805-821. [CrossRef]

59. Ford, J.D.; Ford, L.W.; D'Amelio, A. Resistance to Change: The Rest of the Story. Acad. Manag. Rev. 2008, 33, 362-377. [CrossRef]

60. Ford, J.D.; Ford, L.W. Stop Blaming Resistance to Change and Start Using It. Organ. Dyn. 2010, 39, 24-36. [CrossRef]

61. Piderit, S.K. Rethinking Resistance and Recognizing Ambivalence: A Multidimensional View of Attitudes toward an Organizational Change. Acad. Manag. Rev. 2000, 25, 783. [CrossRef] 
62. Oreg, S. Resistance to Change: Developing an Individual Differences Measure. J. Appl. Psychol. 2003, 88, 680-693. [CrossRef] [PubMed]

63. Oreg, S. Personality, Context, and Resistance to Organizational Change. Eur. J. Work Organ. Psychol. 2006, 15, 73-101. [CrossRef]

64. Kotter, J.P. Leading Change: Why Transformation Efforts Fail. Harvard Business Review. 1995, 95204, 59-67.

65. Beckhard, R.; Pritchard, W. Changing the Essence: The Art of Creating and Leading Fundamental Change in Organization, 1st ed.; The Jossey-Bass management series; Jossey-Bass Publishers: San Francisco, CA, USA, 1992; ISBN 978-1-55542-412-1.

66. Ford, J.D.; Ford, L.W. The Role of Conversations in Producing Intentional Change in Organizations. Acad. Manag. Rev. 1995, 20, 541. [CrossRef]

67. Grant, D.; Marshak, R.J. Toward a Discourse-Centered Understanding of Organizational Change. J. Appl. Behav. Sci. 2011, 47, 204-235. [CrossRef]

68. Gagne, M.; Koestner, R.; Zuckerman, M. Facilitating Acceptance of Organizational Change: The Importance of SelfDetermination1. J. Appl. Soc. Psychol. 2000, 30, 1843-1852. [CrossRef]

69. Gopinath, C.; Becker, T.E. Communication, Procedural Justice, and Employee Attitudes: Relationships Under Conditions of Divestiture. J. Manag. 2000, 26, 63-83. [CrossRef]

70. Rafferty, A.E.; Restubog, S.L.D. The Impact of Change Process and Context on Change Reactions and Turnover During a Merger. J. Manag. 2010, 36, 1309-1338. [CrossRef]

71. Kim, T.G.; Hornung, S.; Rousseau, D.M. Change-Supportive Employee Behavior: Antecedents and the Moderating Role of Time J. Manag. 2011, 37, 1664-1693. [CrossRef]

72. Meindl, J.R. The Romance of Leadership as a Follower-Centric Theory: A Social Constructionist Approach. Leadersh. Q. 1995, 6, 329-341. [CrossRef]

73. Bligh, M.C. Followership and Follower-Centred Approaches. In The SAGE Handbook of Leadership; Bryman, A., Collinson, D., Grint, K., Jackson, B., Uhl-Bien, M., Eds.; SAGE Publications Ltd: London, UK, 2011; pp. 425-436.

74. Collinson, D.; Smolović Jones, O.; Grint, K. 'No More Heroes': Critical Perspectives on Leadership Romanticism. Organ. Stud. 2018, 39, 1625-1647. [CrossRef]

75. Bass, B.M.; Avolio, B.J. Transformational Leadership And Organizational Culture. Int. J. Public Adm. 1994, 17, 541-554. [CrossRef]

76. Alvesson, M. Leadership and Organizational Culture. In The SAGE Handbook of Leadership; Bryman, A., Collinson, D., Grint, K., Jackson, B., Uhl-Bien, M., Eds.; SAGE Publications Ltd: London, UK, 2011; pp. 152-164.

77. de la Herrán, A. Técnicas didácticas para una enseñanza más formativa. In Estrategias y Metodologías para la Formación del Estudiante en la Actualidad; Álvarez Aguilar, N., Cardoso Pérez, R., Eds.; Universidad de Camagüey: Camagüey, Cuba, 2011; ISBN 978-959-16-1404-9.

78. Wang, W.; Bai, X.; Xia, F.; Bekele, T.M.; Su, X.; Tolba, A. From Triadic Closure to Conference Closure: The Role of Academic Conferences in Promoting Scientific Collaborations. Scientometrics 2017, 113, 177-193. [CrossRef]

79. Neugebauer, S.; Bolz, M.; Mankaa, R.; Traverso, M. How Sustainable Are Sustainability Conferences?-Comprehensive Life Cycle Assessment of an International Conference Series in Europe. J. Clean. Prod. 2020, 242, 118516. [CrossRef]

80. Chalvatzis, K.; Ormosi, P.L. The Carbon Impact of Flying to Economics Conferences: Is Flying More Associated with More Citations? J. Sustain. Tour. 2021, 29, 40-67. [CrossRef]

81. Bossdorf, O.; Parepa, M.; Fischer, M. Climate-Neutral Ecology Conferences: Just Do It! Trends Ecol. Evol. 2010, 25, 61. [CrossRef]

82. Bonnett, A. The Need for Sustainable Conferences. Area 2006, 38, 229-230. [CrossRef]

83. Achten, W.M.J.; Almeida, J.; Muys, B. Carbon Footprint of Science: More than Flying. Ecol. Indic. 2013, 34, 352-355. [CrossRef]

84. Stroud, J.T.; Feeley, K.J. Responsible Academia: Optimizing Conference Locations to Minimize Greenhouse Gas Emissions. Ecography 2015, 38, 402-404. [CrossRef]

85. Holden, M.H.; Butt, N.; Chauvenet, A.; Plein, M.; Stringer, M.; Chadès, I. Academic Conferences Urgently Need Environmental Policies. Nat. Ecol. Evol. 2017, 1, 1211-1212. [CrossRef]

86. Braa, K.; Vidgen, R. Interpretation, Intervention, and Reduction in the Organizational Laboratory: A Framework for in-Context Information System Research. Account. Manag. Inf. Technol. 1999, 9, 25-47. [CrossRef]

87. Eisenhardt, K.M. Building Theories from Case Study Research. Acad. Manag. Rev. 1989, 14, 532-550. [CrossRef]

88. Hult, M.; Lennung, S.-Å. Towards a Definition of Action Research: A Note and Bibliography. J. Manag. Stud. 1980, 17, 241-250. [CrossRef]

89. Yin, R.K. Case Study Research, Design and Methods, 3rd ed.; Applied Social Research Methods Series; SAGE Publications Ltd: Thousand Oaks, CA, USA, 2003; Volume 5.

90. Yin, R.K. The Case Study as a Serious Research Strategy. Knowledge 1981, 3, 97-114. [CrossRef]

91. Simons, H. Estudio de caso: Teoría y Práctica; Ediciones Morata: Madrid, Spain, 2012; ISBN 978-84-7112-666-5.

92. Galunic, D.C.; Eisenhardt, K.M. Architectural Innovation and Modular Corporate Forms. Acad. Manag. J. 2001, 44, 1229-1249. [CrossRef]

93. Assefa, G.; Frostell, B. Social Sustainability and Social Acceptance in Technology Assessment: A Case Study of Energy Technologies. Technol. Soc. 2007, 29, 63-78. [CrossRef]

94. Austin, G. Case Study and Sustainability Assessment of Bo01, Malmö, Sweden. J. Green Build. 2013, 8, 34-50. [CrossRef]

95. Merriam, S.B. Case Study Research in Education: A Qualitative Approach; Jossey-Bass: San Francisco, CA, USA, 1988; ISBN 978-1-55542-108-3. 
96. Stott, L. Partnership Case Studies in Context; The Partnering Initiative: London, UK, 2005.

97. Emery, F.E.; Trist, E.L. Socio-technical systems. In Management Science, Models and Techniques; Churchman, C.W., Verhulst, M., Eds.; Pergamon: New York, NY, USA, 1960; Volume 2.

98. Susman, G. Action Research: A sociotechnical system perspective. In Beyond Method: Strategies for Social Research; Morgan, G., Ed.; SAGE: Newbury Park, CA, USA, 1983.

99. Latorre Beltrán, A. Latorre Beltrán, A. La investigación acción. In Metodología de la Investigación Educativa; La Muralla: Madrid, España, 2004; pp. 369-394.

100. Coughlan, P.; Coghlan, D. Action Research for Operations Management. Int. J. Oper. Prod. Manag. 2002, 22, 220-240. [CrossRef]

101. Universidad Politécnica de Madrid Seminarios UPM. Eventos Anteriores. Available online: https://www.upm.es/Investigacion /difusion/SeminariosUPM/eventosAnteriores (accessed on 27 July 2021).

102. Saldaña, J. The Coding Manual for Qualitative Researchers, 2nd ed.; SAGE: Los Angeles, CA, USA, 2013; ISBN 978-1-4462-4736-5.

103. Holt, D.T.; Armenakis, A.A.; Feild, H.S.; Harris, S.G. Readiness for Organizational Change: The Systematic Development of a Scale. J. Appl. Behav. Sci. 2007, 43, 232-255. [CrossRef]

104. Universidad Politécnica de Madrid. Convocatoria de Ayudas PDI e Investigadoras Doctores para Fomentar la Colaboración Científica y Tecnológica entre las Estructuras de I+D+i. Available online: https:/ / www.upm.es/Investigacion/Programa_Propio _UPM/2018/infraestructuras?id=2e12b259269a2610VgnVCM10000009c7648a__\&fmt=detail (accessed on 22 July 2021).

105. Mazzucato, M. Mission-Oriented Research E Innovation in the European Union. A Problem-Solving Approach to Fuel Innovation-Led Growth; Publications Office of the European Union: Luxembourg, 2018; ISBN 978-92-79-79918-1.

106. European Commission. Horizon Europe. Available online: https:/ / ec.europa.eu/info/research-and-innovation/funding/fund ing-opportunities/funding-programmes-and-open-calls/horizon-europe_en (accessed on 20 July 2021).

107. EIT Climate-KIC. Transformation in Time. Available online: https://www.climate-kic.org/wp-content/uploads/2018/12/Trans formation-in-time.pdf (accessed on 22 July 2021).

108. Pettigrew, A.M. Longitudinal Field Research on Change: Theory and Practice. Organ. Sci. 1990, 1, 267-292. [CrossRef]

109. Universidad Politécnica de Madrid. La UPM En Cifras 2019. Available online: https:/ / www.upm.es/UPM/UPMCifras (accessed on 12 January 2021).

110. Universidad Politécnica de Madrid. Plan de Sostenibilidad Ambiental. Available online: https://blogs.upm.es/sostenibilidadu pm/wp-content/uploads/sites/759/2020/03/Plan-de-Sostenibilidad-Ambiental-UPM.pdf (accessed on 12 January 2021).

111. Parker, P. The Art of Gathering: How We Meet and Why It Matters; International ed. Riverhead Books: New York, NY, USA, 2018; ISBN 978-1-59463-492-5.

112. Universidad Politécnica de Madrid. Las mujeres en la Universidad Politécnica de Madrid. Available online: http:/ /www.upm.es /sfs/Rectorado/Gerencia/Igualdad/Documentos/Dossier_Mujer_UPM_actualizado_2015.pdf (accessed on 27 July 2021).

113. Universidad Politécnica de Madrid. Youtube Playlist of the "Seminarios UPM: Tecnología e Innovación Para los Objetivos de Desarrollo Sostenible". Available online: https://www.youtube.com/playlist?list=PLazAYOVsmcxBKcxGBZjNnQ_aqqJCfEkIs (accessed on 27 July 2021).

114. Slido. Slido-Audience Interaction Made Easy. Available online: https:/ / www.sli.do (accessed on 27 July 2021).

115. Armenakis, A.A.; Harris, S.G.; Feild, H.S. Making change permanent A model for institutionalizing change interventions. In Research in Organizational Change and Development; Research in Organizational Change and Development; Emerald Group Publishing Limited: Wagon Lane, Bingley, UK, 2000; Volume 12, pp. 97-128, ISBN 978-1-84950-041-8.

116. Weiner, B.J.; Amick, H.; Lee, S.-Y.D. Conceptualization and Measurement of Organizational Readiness for Change: A Review of the Literature in Health Services Research and Other Fields. Med. Care Res. Rev. 2008, 65, 379-436. [CrossRef]

117. Universidad Politécnica de Madrid. Declaration on the Occasion of the 2019 United Nations Climate Change Conference in Madrid COP25. Available online: https://blogs.upm.es/cop25/wp-content/uploads/sites/746/2019/11/Declaration-on-the-O ccasion-of-the-2019-United-Nations-Climate-Change-Conference-in-Madrid-COP25.pdf (accessed on 22 July 2021).

118. Universidad Politécnica de Madrid. Red de Comunidades Temáticas UPM. Available online: https://www.upm.es/Investigaci on/innovacion/Comunidades (accessed on 15 March 2021).

119. Universidad Politécnica de Madrid. Comunidad de Campus Circulares. Available online: https://www.upm.es/Investigacion/i nnovacion/Comunidades/Circulares (accessed on 22 July 2021).

120. Universidad Politécnica de Madrid. Transición Hacia Una Universidad Libre de Emisiones-TULE. Aprovechamiento y Gestión de Recursos Naturales. Available online: https://www.upm.es/Investigacion/innovacion/Comunidades/TULE (accessed on 22 July 2021).

121. Universidad Politécnica de Madrid. Colaboratorio Para La Descarbonización de Los Campus UPM. Available online: https: //www.upm.es/Investigacion/innovacion/Comunidades/Colaboratorio (accessed on 22 July 2021).

122. EELISA. EELISA European University. Available online: https: / / eelisa.eu/ (accessed on 18 June 2021).

123. Universidad Politécnica de Madrid. Nace el Comité para la Descarbonización de la UPM. UPM Sosten. Available online: https:/ / sostenibilidad.upm.es/nace-el-comite-para-la-descarbonizacion-de-la-upm/ (accessed on 22 July 2021).

124. Blythe, J.; Cvitanovic, C. Five Organizational Features for Successful Interdisciplinary Research. Available online: https: //i2insights.org/2021/01/26/context-for-successful-interdisciplinarity / (accessed on 9 August 2021). 